\title{
What price of speed? A critical revision through constructal optimization of transport modes
}

\author{
Michele Trancossi
}

Received: 30 June 2014 / Accepted: 6 January 2015/Published online: 10 February 2015

(c) The Author(s) 2015. This article is published with open access at Springerlink.com

\begin{abstract}
The use of energy by the major modes and the environmental impact of freight transportation is a problem of increasing importance for future transportation policies. This paper aims to study the relative energy efficiency of the major transport modes, setting up an impartial analysis, improving previous literature substantially. Gabrielli and von Karman have studied the relationship between speed and energy consumption of the most common transport modes. From this pioneering activity different methods for evaluating the energetic performance of vehicles have developed. Initially the maximum vehicle power and theoretical performance limits have been calculated in terms of weight and payload. Energy efficiency has then been evaluated in terms of the first principle of thermodynamics as the mass of the vehicle times distance moved divided by thermal energy used. A more effective analysis can be performed both in terms of vehicle life cycle and in terms of second principle considering the quality and the amount of dissipated amount of useful energy. This paper defines an LCA based model, which could allow an effective comparison between different transport modes classifying them in terms of exergy destruction. In this case, an effective comparison, which considers the quality of used energy, can be performed allowing precise politics for a future more effective evaluation of the transport modes.
\end{abstract}

Published in the Special Issue "8th AIGE Conference (Italian Association for Energy Management)".

M. Trancossi ( $\square)$

Di.S.M.I., University of Modena and Reggio Emilia,

Via Amendola n. 2, 42100 Reggio Emilia, Italy

e-mail: michele.trancossi@unimore.it
Keywords Transport - Energy efficiency · Velocity · Consumption · Exergy · Gabrielli-Von Karman

\section{List of symbols}

DT Delivery time (S)

$E_{\text {kin }} \quad$ Kinetic energy (MJ)

$E_{\mathrm{D}} \quad$ Energy dissipation against drag (MJ)

$E_{\mathrm{ROL}} \quad$ Rolling energy (MJ)

Ex $_{\text {payload }}$ Exergy dissipated by payload (MJ)

$\mathrm{Ex}_{\text {res }} \quad$ Exergy from resources (MJ)

Ex $_{\text {service }}$ Exergy dissipated during service (MJ)

Ex $x_{\text {vehicle }}$ Exergy dissipated by vehicle (MJ)

$N \quad$ Number of travels

$m_{\mathrm{p}} \quad$ Mass of payload $(\mathrm{kg})$

$m_{\mathrm{v}} \quad$ Mass of vehicle $(\mathrm{kg})$

MPST Mass per single transport (ton)

$P_{\max } \quad$ Maximum power $(\mathrm{kW})$

TD Total distance $(\mathrm{km})$

TM Total mass (Ton)

TD Total distance (S)

$V \quad$ Velocity $(\mathrm{m} / \mathrm{s})$

$v_{\text {av }} \quad$ Average velocity

$v_{\max } \quad$ Maximum velocity $(\mathrm{m} / \mathrm{s})$

$W \quad$ Weight $(\mathrm{N})$

$\varepsilon \quad$ Specific resistance of vehicle

$\varepsilon_{\mathrm{f}} \quad$ Fuel transport effectiveness

$\zeta \quad$ Energy per unit volume of fuel $\left(\mathrm{MJ} / \mathrm{kg}_{\text {fuel }}\right)$

$\eta \quad$ Distance traveled per unit volume of fuel $(\mathrm{Km} /$ $\mathrm{kg}_{\text {fuel }}$ )
Abbreviations
EMIPS Exergetic material input pro unit of service
LCA Life cycle assessment
LHV Low heating value
GHG Green house gas 


\section{Introduction}

Energy demand is growing, affordable and secure energy supply are fundamental to global economic growth and human development. The scenario described by "World Energy Outlook 2013" [1] (WEO 2013) together with the forecasts by "2014 World Energy Issues Monitor" [2] (2014 WEIM) presents large uncertainness about future and a dramatic increase in terms of energy demand, driven by non-OECD economic growth. Figure 1 shows historical data by WEO 2013 and Fig. 2 present provisional data by 2014 WEIM.

Future energy perspectives present diffused uncertainness related to the high volatility of energy prices, the lack of global agreement on climate change mitigation, the necessary demand for new energy infrastructures, too slow development of Carbon capture technologies, and the necessity of increasing energy efficiency.

It is evident that the provisions for the future are out of the sustainability of the planet, both in terms of destruction of resources and in terms of climate change, which directly related to the emission in terms of GHG.

\section{Transport sector overview}

Even if it is not the main contributor to the energy consumption, the transport sector will play a fundamental role for the future wellness of the humanity. In particular, energy use in the transportation sector includes energy consumed in moving people and goods by road, rail, air, water, and pipeline. Those transportation systems are essential in an increasingly globalized world, as well as for enhancing standards of living.

Trade and economic activity seem the most significant factors increasing demand for freight transportation. The factors that will affect the demand of passenger transportations appear much more complex and include uncertain

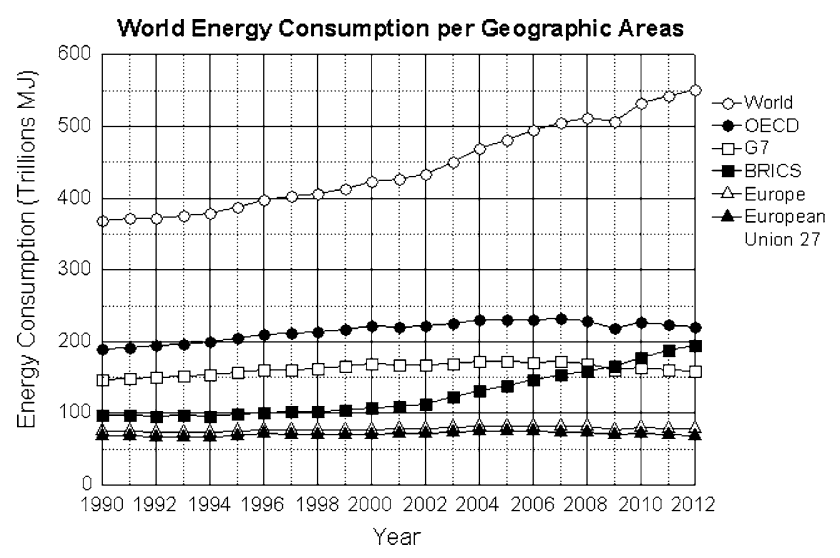

Fig. 1 World Energy Consumption historical trend (data from IEA WEO 2013)

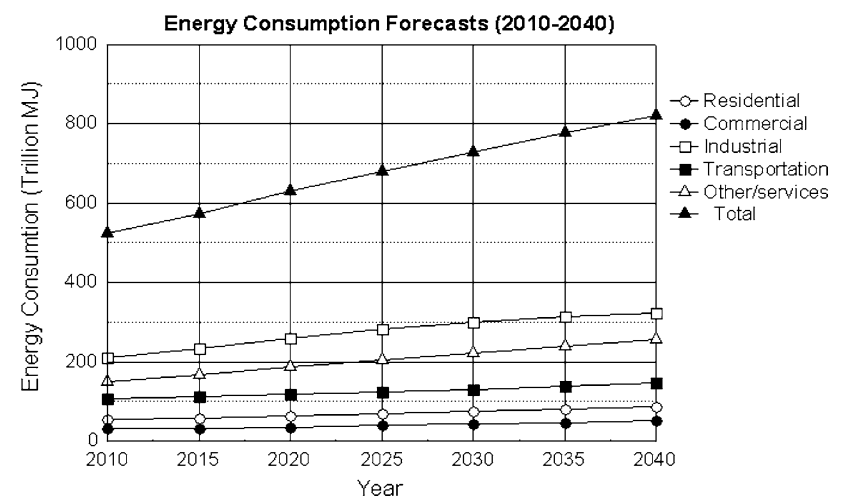

Fig. 2 Energy consumption Forecast 2010-2040 (data by 2014 WEIM)

parameters such as travel behavior, land use patterns, and urbanization. This increased complexity presents a larger uncertainness about - the effects of passenger transportation in terms of macroeconomic and fuel market impacts.

Any possible analysis of energetic impact of transport modes must necessary consider different modes and their energy efficiency to allow the definition of effective strategies to reduce the energy consumption, by adopting the two main decisional elements for the future. In particular, they are a short-term strategy based on a better planning of transport modes and on a long-term strategy based on substantial improvements of vehicles.

Any analysis about transport modes must considers two fundamental parameters they are speed and energy intensity. Increasing speed increases social efficiency and allows reducing costs for both public and private institutions and for citizens. On the other side, energy consumption causes economic, environmental and social costs.

An overview of scientific literature

The first fundamental attempt to analyze the relations between speed and energy consumption of different transport modes has been produced by Gabrielli and von Karman [3]. This analysis introduces a physical parameter, named specific resistance of vehicle $\varepsilon$, which is defined as the ratio of motor output power $P_{\max }$ divided by the product of total vehicle weight $W$ by maximum speed $V_{\max }$.

$\varepsilon=\frac{P_{\max }}{W \cdot V_{\max }}$

It is fundamental to notice that Gabrielli and Von Karman consider the gross weight of the vehicle, because "exact information about the useful load of vehicles was not available to the authors." They have clearly demonstrated that specific resistance has a minimum value, which applies to all the examined transport modes, which appears as a physical limit of all transport modes. It corresponds to the line of equation 


$$
\varepsilon_{\min }=A \cdot V_{\max }
$$

where $A=0.000175 \mathrm{~h} / \mathrm{mile}$. The Gabrielli-von Karman limit line of vehicular performances depicts this relationship. It is the diagonal line indicated in Fig. 3.

Stamper [4] reconsidered Gabrielli-von Karman results in terms of ratio between payload weight and fuel consumption, introducing one of the future trends of transport energy efficiency in terms of payload of the different vehicles, without considering the vehicle as a part of the transported weight. Stamper has defined "useful transport work" by multiplying payload weight and distance traveled and "transport efficiency" as the ratio of useful transport work to thermal energy expended. This model is useful on a logistic point of view but losses any physical connection to the real nature of transport which is composed by two fundamental elements, the vehicle and the payload.

In a subsequent analysis, Teitler and Proodian [5] have categorized military vehicles and have considered a new characteristic dimension, which has named "specific fuel expenditure", which can be defined as
$\varepsilon_{\mathrm{F}}=\frac{\zeta}{\eta \cdot W_{\mathrm{P}}}$

where $\zeta$ is the energy per unit volume of fuel $\eta$ is the distance traveled per unit volume of fuel, and $W_{\mathrm{P}}$ is the weight of the payload. A new variable has been introduced it is the reciprocal of $\varepsilon_{F}$ has been defined as "fuel transport effectiveness", which relates directly to the cruising speed of the vehicle $V_{\mathrm{C}}$ by a factor of proportionality $C_{\mathrm{F}}$ :

$\frac{1}{\varepsilon_{\mathrm{F}}}=\frac{1}{C_{\mathrm{F}} \cdot V_{\mathrm{C}}}$

This definition allows defining the factor of proportionality $C_{\mathrm{F}}$ as the "the next level of fuel transport effectiveness to be used as a future standard", which is represented in Fig. 4, with the dashed diagonal line [6].

Referencing Gabrielli-von Karman [1] and Teitler and Proodian [3], Minetti [7], Young [8] and Hobson [9] have considered $A$ or $C_{\mathrm{F}}$ as a factor describing an experiential performance limit and $\varepsilon_{\mathrm{F}}^{-1}$ or $\varepsilon_{\mathrm{F}}$ as a general performance parameter.
Fig. 3 Gabrielli-Von Karman graph (from Neodymics [4] )

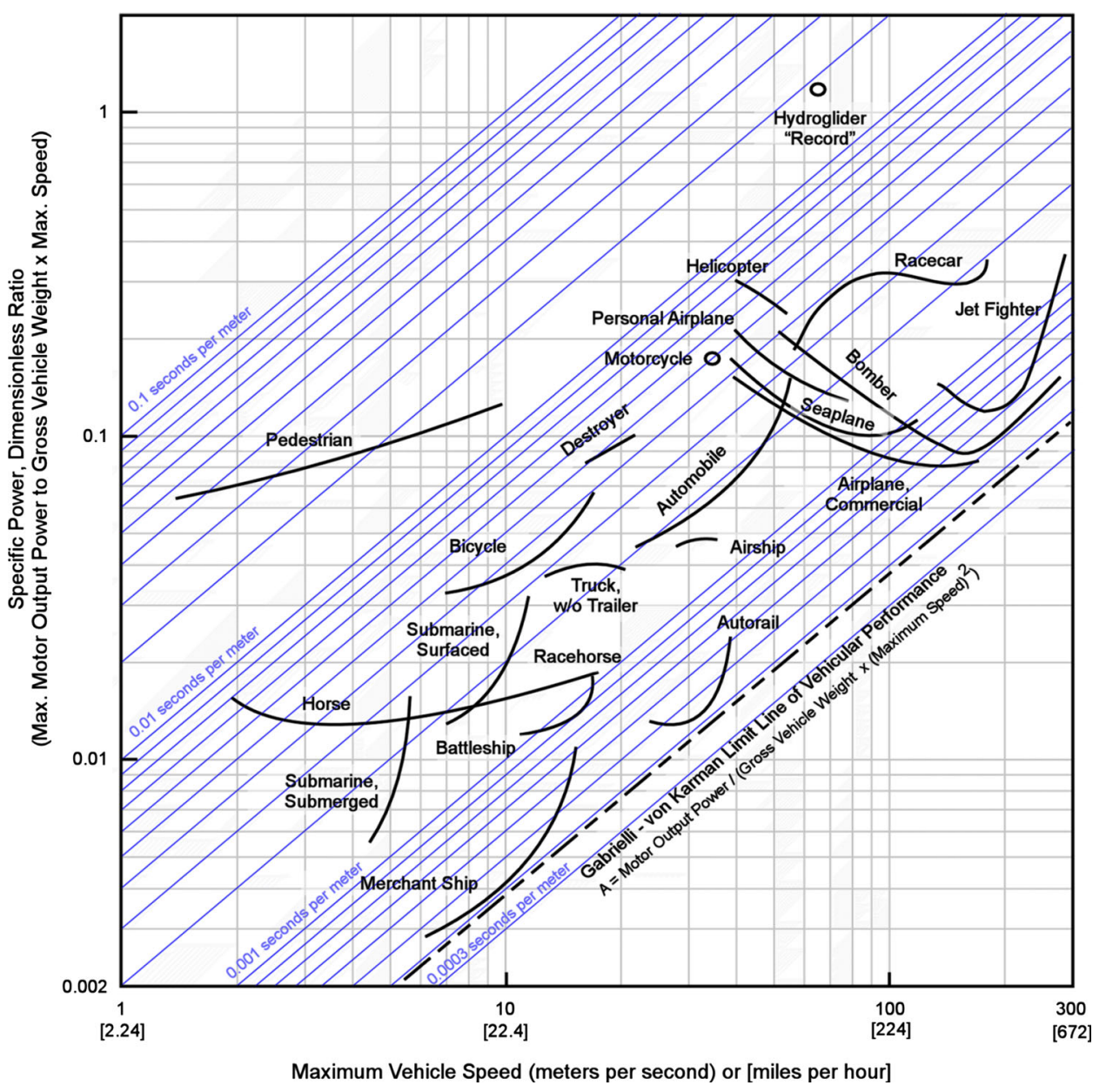


Fig. 4 Dimensionless fuel transport effectiveness plotted as a function of cruise speed (adapted from Teitler and Proodian [5] by Neodymics [4] )

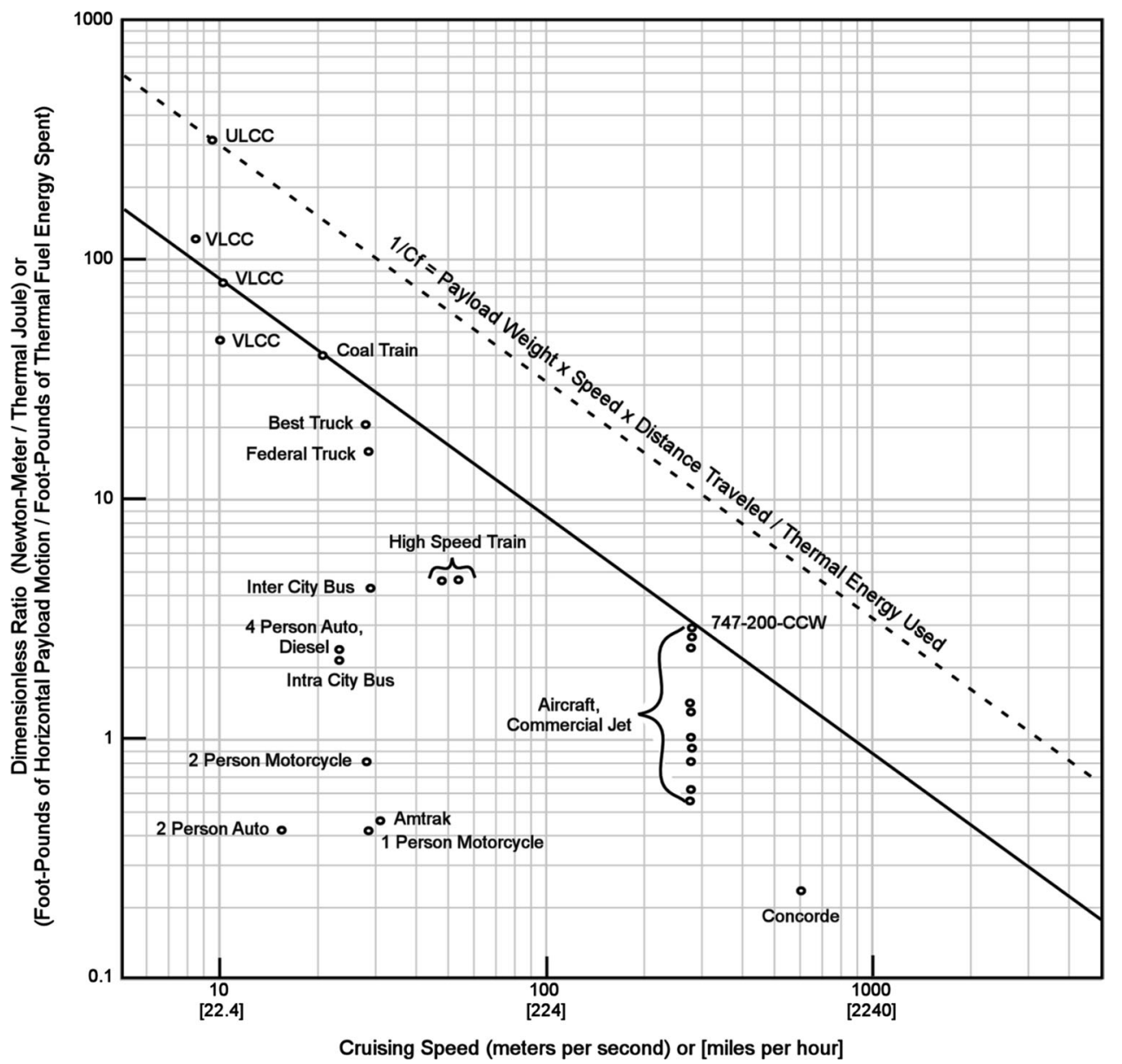

Radtke [10] has produced a further development of the above models. He observed that by combining speed and energy expenditure it could be obtained a novel performance parameter $\varepsilon_{\mathrm{F}}$, which considers payload and energy needs under cruising conditions. Those considerations allow obtaining a new performance parameter $Q_{\mathrm{C}}$ obtained by treating the payload as a mass (denoted $M_{\mathrm{P}}$ ) rather than a weight yields a performance parameter $Q$ with units of time. For cruise conditions, $Q_{\mathrm{C}}$ has been obtained:

$Q_{\mathrm{C}}=\frac{g_{\mathrm{o}}}{C_{\mathrm{F}}}=V_{\mathrm{C}} \cdot M_{\mathrm{P}} \cdot \frac{\eta}{\zeta}$

Radtke has used certified data such as the EPA fuel economy ratings to represent how vehicles are actually used. In particular, he adopted the highway rating which is used to describe free flow traffic at highway speeds [11]. $\mathrm{He}$ has the produced an energetic analysis of different vehicles including aircrafts and electric vehicles.

Dewulf and Van Langenhove [12] have adopted a completely different approach based on an elementary exergetic analysis. They present an effective assessment of the sustainability of transport technologies in terms of resource productivity, based on the concept of material input per unit of service (MIPS). If MIPS evaluation is quantified in terms of the second law of thermodynamics, it is possible to calculate both resource input and service output in exergetic terms. It leads to the concept of EMIPS (acronym of Exergetic Material Input per Unit of Service) specifically defined for transport technology. It takes into account the total mass to be transported and the total distance, but also the mass per single transport and the speed, allowing an effective comparison between railway, truck, and passenger car transport.

Transport modes and vehicles has been then evaluated in terms of exergetic material input pro unit of service (EMIPS):

$R / S=\frac{\text { Ex }_{\text {resources }}}{\text { Ex }_{\text {service }}}=$ EMIPS

The amount of resources extracted from the ecosystem to provide the transport service has quantified defining an inventory of all exergetic resources in the whole life cycle. 
The method allows evaluating cumulative exergy consumption also introducing an effective differentiation between non-renewable and renewable resource inputs according to Gong and Wall [13].

Dewulf has evaluated the exergy associated with the transport to overcome aerodynamic resistance, inertia effects and friction to bring a total mass (TM) in a number of transports $(N)$ with a mass per single transport (MPST) within a delivery time (DT) over a total distance (TD). The physical requirement is the exergy to accelerate and to overcome friction. If one is able to define the exergy associated to this service, being a function of TM, MPST, DT, and TD, then the exergetic efficiency of transport technology can be determined:

$R / S=\mathrm{EMIPS}=\frac{\text { Ex }_{\text {resources }}}{\operatorname{Ex}_{\text {service }}(\mathrm{TM}, \mathrm{MPST}, \mathrm{DT}, \mathrm{TD})}$

Dewulf takes into account two types of dissipations: $E_{\text {kin }}$, kinetic energy, and $E_{\mathrm{D}}$ to overcome the aerodynamic drag.:

$E_{\mathrm{d}}=E_{\mathrm{kin}}+E_{\mathrm{D}}$

where the kinetic energy depends on the maximum speed $v_{\max }$ during the trajectory: $v=v_{\max }$ if $v \neq 0$ and $d v / d t=0$.

$E_{\mathrm{kin}}=\frac{1}{2} m \cdot v_{\max }^{2}$

On the other hand, for a given shape vehicle aerodynamic resistance causes an energetic loss

$E_{\mathrm{D}}=\int_{0}^{t_{\text {tot }}}\left(\frac{1}{2} \cdot C_{\mathrm{D}} \cdot \rho \cdot A \cdot v^{2}\right) \cdot v \cdot d t$

where $C_{\mathrm{D}}$ is the drag coefficient, $A$ is the cross section, and $\rho$ is the density of air. It can be observed that high speed is very unfavorable, because the energy losses due to aerodynamic resistance relates to $v^{3}$. Wind direction has been reasonably neglected assuming that it varies casually with an almost uniform distribution and that the number of transports inwind is the same as the ones upwind.

The final expression of the exergy service has been expressed as:

$\mathrm{Ex}_{\text {service }}=\frac{\mathrm{TM}}{\mathrm{MPST}}\left(\frac{1}{2} \mathrm{MPST}_{\frac{\mathrm{TD}^{2}}{\mathrm{DT}^{2}}}+\frac{1}{2} C_{\mathrm{D}} \rho A \frac{\mathrm{TD}^{3}}{\mathrm{DT}^{2}}\right)$

Chester and others [13-15] have studied the environmental life cycle assessment (LCA) of transportation systems. They create a framework for assessing the energy use and resulting environmental impacts of passenger and freight mobility, comparing the equivalent energy or environmental effects of different technologies or fuels. They have produced an effective LCA framework for the assessment of transportation systems, which includes vehicle technologies, engine technologies, fuel/energy pathways, infrastructure, and supply chains. This research has been focused on developing a suitable LCA framework for policies and decisions. In particular, different energetic consumption has been evaluated all over the whole product lifecycle. Figure 5 shows a sample of the analysis, which can be produced by applying Chester methodology [15].

\section{Objectives}

This research, aims to produce a robust model, which can allow comparing different transport modes and overcome the limits of preceding research.

It aims to define an effective model with a set of fundamental goals. In particular, it aims defining an effective and robust model, which takes into account the complexity of the energetic factors related to transport.

Referring to preceding literature, it aims to overcome the generality of the Gabrielli-von Karman analysis [3], but it aims to consider the vehicle as a whole, such as they do. They miss an effective evaluation of the energy necessary for moving the vehicle itself and the energy necessary for moving the payload.

The proposed analysis is fundamental for understanding future directions of vehicle improvement. It aims to overcome the analysis by the author, influenced by logistical issues, which refers the energy consumption to the payload [4-10]. It also aims improving both Dewulf exergetic analyses by considering a more analytical differentiation of energy dissipations during service. It appears clear that Dewulf model misses an evaluation of rolling dissipation, which are not negligible and could not be merged with aerodynamic drag, because of a completely different nature and physical law.

Even if it moves in the direction traced by Chester [1315], it aims to consider also the necessary amount of energy for dismantling and recycling the materials of the vehicle, opening the road to a better LCA management.

Comparing Dewulf and Chester results, which are completely compatible it appears evident the differences between exergetic and energetic analysis, even if both evidences the dominant contributions to energy consumption and GHG emissions for on-road and air modes are from components that relate directly to transport operations.

\section{General analysis}

Energy efficiency of transport modes

The necessity of focusing the attention on the transport sector is clearly stated by IPCC Fourth Assessment Report: 


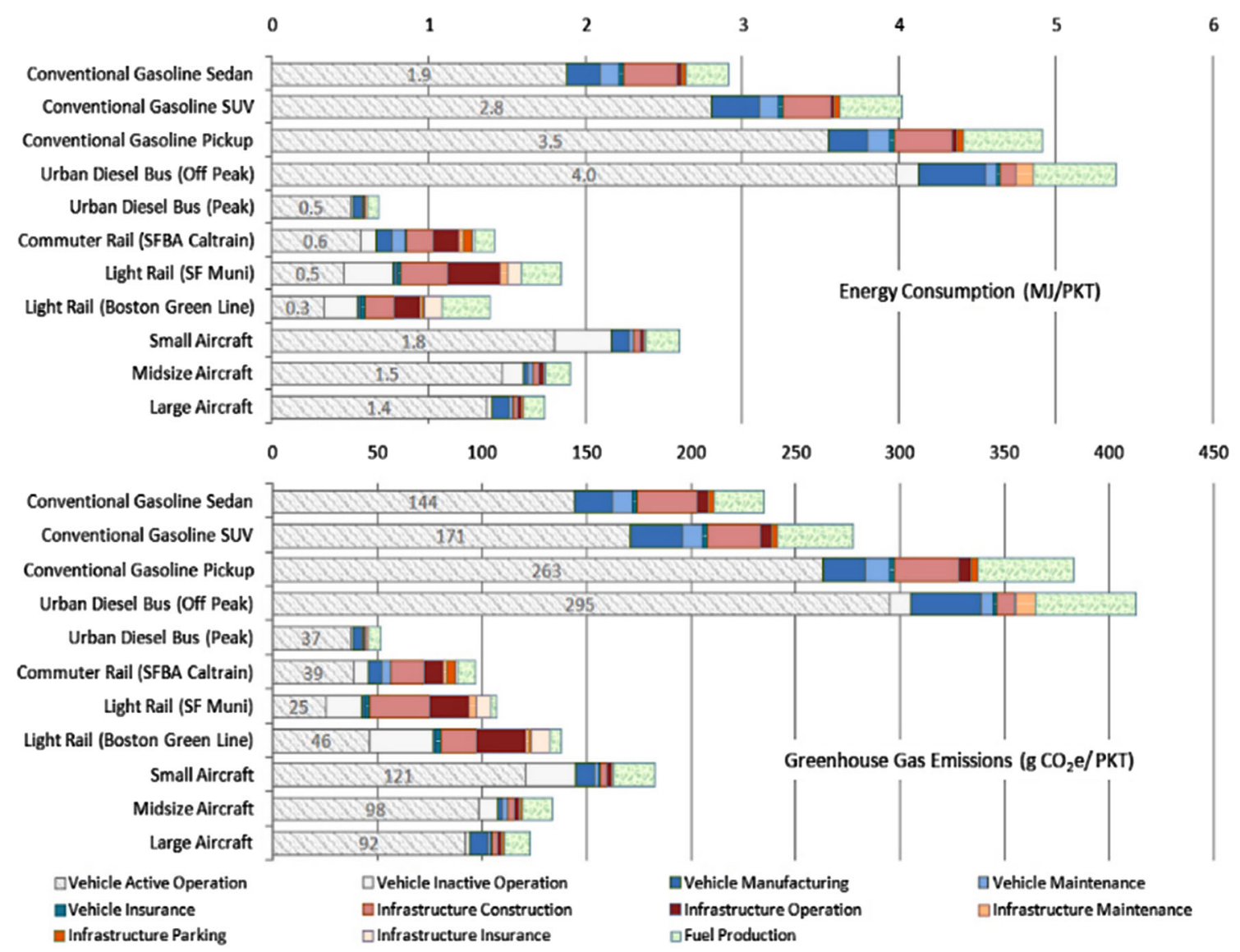

Fig. 5 Energy consumption and GHG emissions by different transport modes (from Chester and others [15] )

Fig. 6 World GHG emissions (source: IPCC Fourth Assessment Report: Climate Change 2007)

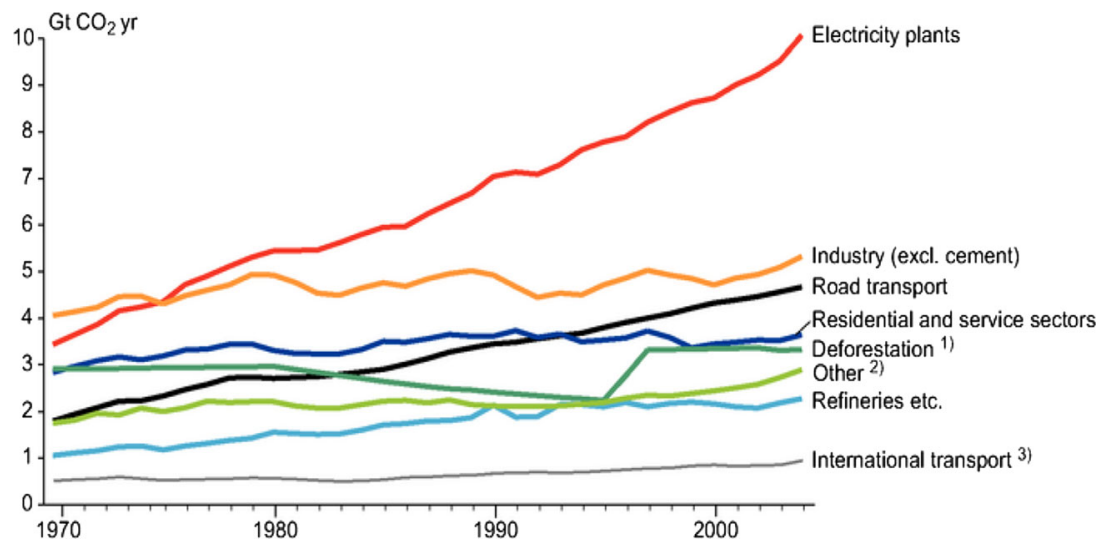

well tested method by Chester. It has been completed by introducing the dismantling and recycling energetic fees to define a fully sustainable life cycle assessment of the different transport systems. Service energy dissipation has also been divided into requirements for the vehicle and requirements for the payload [17]. Dewulf indicates two dissipative terms kinetic and aerodynamic. In the case of ground vehicles and during takeoff and landing operations performed by aircrafts it is necessary to consider also a 
rolling dissipative term, which depends on the friction of the wheels with the terrain. A more complete analysis in terms of energetic loads can be then performed and they are:

1.

Kinetic term $\quad E_{\text {kin }}=\frac{1}{2} \cdot\left(m_{\mathrm{v}}+m_{\mathrm{p}}\right) \cdot v_{\max }^{2}$

2.

Rolling term $\quad E_{\text {rol }}=c \cdot\left(m_{\mathrm{v}}+m_{\mathrm{p}}\right) \cdot g \cdot v_{\mathrm{av}} \cdot t$

3.

Aerodynamic term $\quad E_{\mathrm{D}} \cong \frac{1}{2} C_{\mathrm{D}} \cdot A \cdot \rho \cdot v_{\mathrm{av}}^{3} \cdot t$

In the case of aircraft, it has been considered tree different moments:

1. Take off: all terms are present and also lifting component of forces must be considered,

2. Flight: aerodynamic term is dominant,

3. Landing: all terms are present and lifting component of forces must be considered.

In the case of ships only kinetic and hydrodynamic term are present (dimensionally equal to the aerodynamic one).

The other energetic terms not directly related to motion have been evaluated according to Chester. In particular, Chester analysis has been implemented by considering also the necessary energy amount for dismantling and recycling the vehicles. Chester uses a hybrid LCA model for this analysis. The components are evaluated from the materials extraction through the final industrial product including supply chains. For example, the evaluation of automotive manufacturing includes the energy and emissions from extraction of raw materials (i.e., iron ore for steel) through the assembly of that steel in the vehicle. End of life phases are not included due to the complexities of evaluating waste management options and material reuse. Indirect impacts are included, i.e., the energy and emissions resulting from the support infrastructure of a process or product, such as electricity generation for automobile manufacturing. For each component in the mode's life cycle, environmental performance is calculated and then normalized per passenger kilometer traveled (PKT). The energy inputs and emissions from that component may have occurred annually (such as from electricity generation for train propulsion) or over the component's lifetime (such as train station construction) and are normalized.

Equation (1) provides the generalized formula by $\mathrm{Ch}$ ester for determining component energy or emissions.
$\mathrm{EM}=\sum_{\mathrm{c}}^{\mathrm{C}} \frac{\mathrm{EF}_{\mathrm{M}, \mathrm{c}} \times U_{\mathrm{M}, \mathrm{c}}(t)}{\operatorname{PKT}_{\mathrm{M}}(t)}$

where

- $\mathrm{EF}_{\mathrm{M}, \mathrm{c}}$ is total energy or emissions per $P K T$ for mode $M$;

- $M$ is the set of modes \{sedan, train, aircraft, etc.\};

- c is vehicle, infrastructure, or fuel life cycle component,

- $\mathrm{EF}$ is environmental (energy or emission) factor for component c,

- $\quad U$ is activity resulting in $\mathrm{EF}$ for component c;

- $\mathrm{PKT}_{\mathrm{M}}$ is PKT performed by mode M during time $t$ for component $\mathrm{c}$.

The environmental factors used for energy and emissions evaluations come from a variety of sources. In particular, it has been massively used the data obtained by Australian Environmental Protection Authority [18], Nissan-Global [19].

In particular, Choate and others [20] allow deriving a detailed data table about energy saving by recycling different materials. Table 1 shows energy savings comparing different management strategies for material used in automotive industry.

According to these data and assuming a specific mass balance from different authors [21-24] an effective evaluation of End of Life operations of different kinds of vehicles, including possible recycling of components and materials can be performed. This analysis allows defining the energetic parameters related to the entire lifecycle of the vehicle and considered an initial sample of about 50 vehicles chosen on their representation of the category. Fuels have been evaluated using the values in Table 2, which have been defined by Tupras report [37]. Other relevant energy losses have been evaluated according to Chester [13-15], including infrastructure. Averaged data for vehicle category have been reported in Fig. 7. Results that are more detailed have been presented in "Appendix 1".

Further considerations allow to go forward considering the general expression of the kinetic and rolling term of the dissipative terms.

The general expression of the dissipative term is then

$\mathrm{Ex}_{\text {service }}=\mathrm{Ex}_{\mathrm{rol}}+\mathrm{Ex}_{\mathrm{kin}}+\mathrm{Ex}_{\mathrm{D}}$

In addition, two different terms referred to the vehicle and payload can be determined. In particular,

$\mathrm{Ex}_{\mathrm{vehicle}}=m_{\mathrm{v}}\left(\operatorname{cg} v_{\mathrm{av}} t+\frac{1}{2} v_{\mathrm{max}}^{2}\right)+\frac{1}{2} C_{\mathrm{D}} A \rho_{\mathrm{air}} v_{\mathrm{av}}^{3} t$

is the component due to vehicle even at zero payload, and

$\mathrm{Ex}_{\text {payload }}=m_{\mathrm{p}}\left(\operatorname{cg} v_{\mathrm{av}} t+\frac{1}{2} m_{\mathrm{p}} v_{\max }^{2}\right)$

is the component due to payload. 
Table 1 Energy consumed/avoided from different waste involved in vehicle industry and different management options (Million Btu/Ton)

\begin{tabular}{|c|c|c|c|c|}
\hline Material & $\begin{array}{l}\text { Source } \\
\text { reduction } \\
\text { for } \\
\text { current } \\
\text { mix of } \\
\text { inputs }\end{array}$ & Recycling & Combustion & Landfilling \\
\hline Aluminum & -126.18 & -206.42 & 0.12 & 0.53 \\
\hline Steel & -30.79 & -19.97 & -17.54 & 0.53 \\
\hline Copper & -122.31 & -82.59 & 0.1 & 0.53 \\
\hline Glass & -7.53 & -2.13 & 0.08 & 0.53 \\
\hline HDPE & -63.68 & -50.9 & -6.66 & 0.53 \\
\hline LDPE & -73.92 & -56.01 & -6.66 & 0.53 \\
\hline PET & -70.67 & -52.83 & -3.46 & 0.53 \\
\hline Paper & -36.58 & -10.08 & -2.13 & 0.13 \\
\hline Mixed metals & NA & -102.99 & 0.39 & 0.53 \\
\hline Mixed plastics & NA & -52.42 & -5.09 & 0.53 \\
\hline $\begin{array}{l}\text { Mixed } \\
\text { recyclables }\end{array}$ & NA & -16.91 & -2.06 & 0.36 \\
\hline $\begin{array}{l}\text { Mixed } \\
\text { organics** }\end{array}$ & NA & 0.58 & -0.58 & 0.41 \\
\hline $\begin{array}{l}\text { Personal } \\
\text { computers }\end{array}$ & -950.16 & -43.43 & -0.55 & 0.53 \\
\hline
\end{tabular}

**The composition of organic material is subject to a great variability. It has been assumed a value derived from EU average waste composition

Table 2 Properties of different fuels adopted

\begin{tabular}{lllll}
\hline Fuel forms & $\begin{array}{l}\text { LHVs } \\
(\mathrm{MJ} / \mathrm{kg})\end{array}$ & $\begin{array}{l}\text { Exergy } \\
\text { factors }\end{array}$ & $\begin{array}{l}\text { Exergy } \\
(\mathrm{MJ} / \mathrm{kg})\end{array}$ & $\begin{array}{l}\text { Density } \\
\left(\mathrm{kg} / \mathrm{m}^{3}\right)\end{array}$ \\
\hline Gasoline & 43.1 & 1.06 & 45.7 & 737 \\
Diesel oil & 42.7 & 1.07 & 45.6 & 870 \\
Kerosene & 43.1 & 1.07 & 46.1 & 790 \\
Fuel oil & 41.8 & 1.06 & 44.3 & 890 \\
Natural gas & 38.1 & 1.04 & 39.6 & 0.9 \\
$\begin{array}{l}\text { LPG } \\
\begin{array}{l}\text { Other petroleum } \\
\text { products }\end{array}\end{array}$ & 50.2 & 1.06 & 53.2 & 2.1 \\
\hline
\end{tabular}

This analysis on energy needs for moving the vehicle and energy needs for moving the payload can be produced for different kinds of vehicles.

It allows a better comprehension of energy dissipations of different class of vehicles and allows understanding losses due to today's vehicle industrial concepts. Results have been reported in tabular form in "Appendix 2", both in $\mathrm{MJ} / \mathrm{t} \mathrm{km}$ and in percent comparison.
Life cycle analysis of transport modes

An analysis on energy impact of different transport modes must necessarily consider the intensity of different transport modes on a global scale. They have been obtained by [26] and [27] and reported in Table 4.

Table 3 refers to energetic values in terms of fuel needs and do not consider life cycle needs. Considering the precedent preliminary impacts of different energy dissipations, a complete evaluation of the entire life cycle of existing transport modes have been produced.

These considerations force to actualize the values in Table 3 referring them to the full life cycle of today's circulating fleets, and values are reported in Table 4.

Environmental considerations

Taking into account the Greet 1 Model [28] by Argonne National Laboratory, the Greenhouse Gas Protocol [29], and American Petroleum Institute [30], it is possible to extend the analysis by an evaluation of the emissions of different transport modes per $\mathrm{km}$. The properties of the most used fuels have been presented in Table 5 .

Default fuel economy factors for different types of mobile sources and activity data have been modeled according to EPA [31] and reported in Table 6 (Fig. 8).

The evaluation of energetic impact of different transport modes on global scale allows understanding that the larger impact on the energetic issues is caused by ground transports and in particular by cars. Interpolating the data in Table 6 it can be expressed the $\mathrm{CO}_{2}$ emissions as a function of vehicle consumption in $\mathrm{km} / \mathrm{l}$ (Fig. 9).

The data in Table 6 and in Fig. 9 shows an anomaly constituted by Diesel busses, which is clearly caused by the operational behavior of this vehicle and its mission, which are characterized by frequent stops and go.

The most important result of this analysis has been the definition of an interpolating function, which allows an approximate estimation of emissions as a function of the fuel consumed for moving.

Considering the vehicles previously estimated this system for predicting allows obtaining the general results reported in "Appendix 3". Looking at the results it is evident that emission and energy consumption for ton of payload is much more important for ground transportation and personal transports rather than for other systems. It is also evident that the energy consumed and emissions are lower for freight transport systems rather than for passenger transport. The values in Table 6 take into account an estimation of the whole life cycle emissions. 
Fig. 7 Percent values of Energy consumption for different transport modes

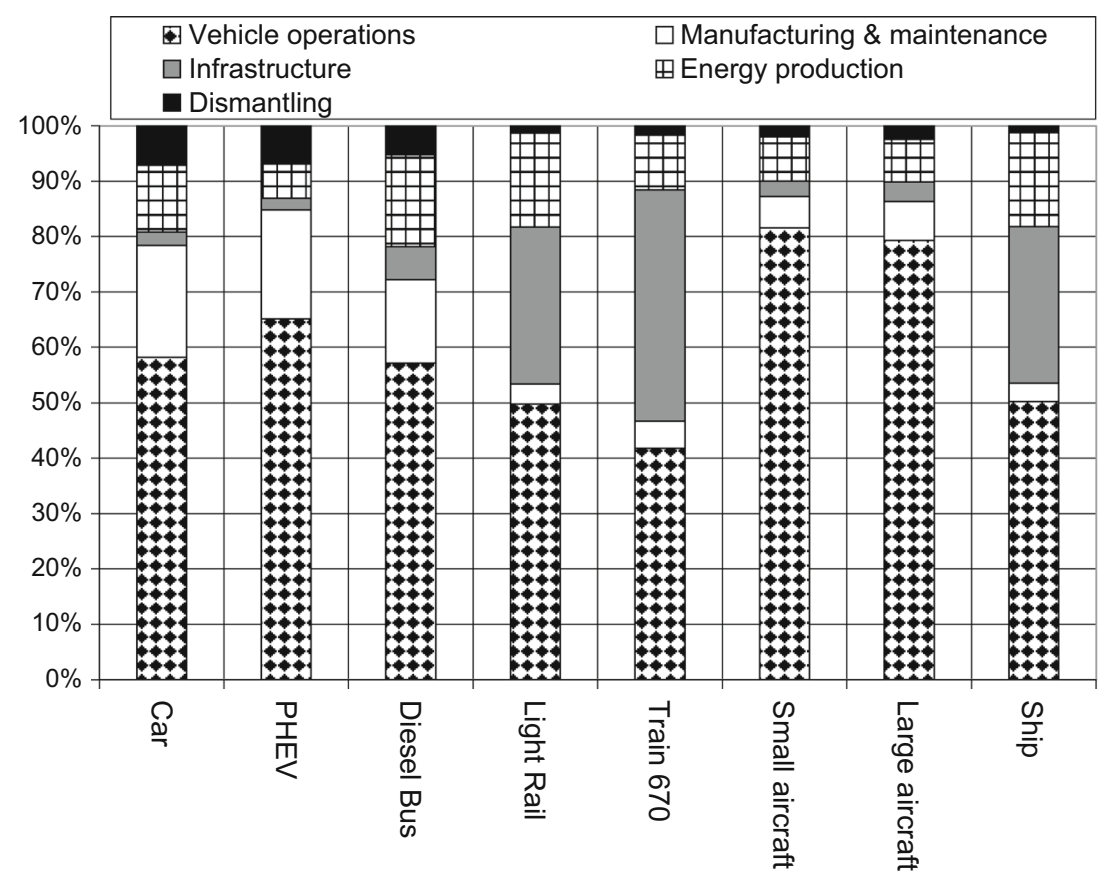

Table 3 Default fuel economy factors for different types of mobile sources and activity data (derived from [25] )

\begin{tabular}{|c|c|c|c|}
\hline \multicolumn{3}{|l|}{ Vehicle characteristics } & \multirow{2}{*}{$\begin{array}{l}\mathrm{CO}_{2} \text { emitted } \\
\mathrm{gCO}_{2} / \mathrm{km}\end{array}$} \\
\hline Vehicle type & $\mathrm{km} / \mathrm{l}$ & $\mathrm{MJ} / \mathrm{km}$ & \\
\hline Light motorcycle & 25.64 & 1.03 & 93.0 \\
\hline New small gas/electric hybrid & 23.81 & 1.11 & 100.1 \\
\hline Small gas auto, hwy & 13.7 & 1.93 & 175.1 \\
\hline Medium gas auto, hwy & 12.82 & 2.06 & 186.8 \\
\hline Medium station wagon, hwy & 11.49 & 2.30 & 207.5 \\
\hline Small gas auto, city & 11.11 & 2.38 & 215.5 \\
\hline Large gas automobile, hwy & 10.64 & 2.48 & 224.1 \\
\hline Diesel automobile & 10.2 & 2.59 & 233.0 \\
\hline Mini van, hwy & 10.2 & 2.59 & 233.5 \\
\hline Medium gas auto, city & 9.35 & 2.82 & 254.7 \\
\hline Mid size pick-up trucks, hwy & 9.35 & 2.82 & 254.7 \\
\hline LPG automobile & 8.93 & 2.96 & 266.0 \\
\hline Med station wagon, city & 8.47 & 3.12 & 280.1 \\
\hline Large gas automobile, city & 7.63 & 3.46 & 311.3 \\
\hline Mini van, city & 7.63 & 3.46 & 311.3 \\
\hline Large van, hwy & 7.63 & 3.46 & 311.3 \\
\hline Large pick-up trucks, hwy & 7.63 & 3.46 & 311.3 \\
\hline Pick-up trucks, city & 7.25 & 3.64 & 329.6 \\
\hline Large pick-up trucks, city & 6.37 & 4.14 & 373.5 \\
\hline Diesel light truck & 6.37 & 4.14 & 374.0 \\
\hline Gasoline light truck & 5.95 & 4.44 & 400.0 \\
\hline Large van, city & 5.95 & 4.44 & 400.2 \\
\hline Diesel heavy truck & 2.98 & 8.86 & 870.0 \\
\hline Diesel bus & 2.85 & 9.26 & $1,034.6$ \\
\hline Gasoline heavy truck & 2.55 & 10.35 & 924.0 \\
\hline
\end{tabular}

Discussion of life cycle results

The results of this analysis of transport modes shows that energy consumption and pollution are mostly caused by ground transportation. In addition the show that energy dissipated for moving road vehicles is much higher than the one for moving their payload ("Appendix 2"). Considering different kinds of vehicles further considerations can be performed. "Appendix 3" reports evaluation of life cycle energetic performances in terms of vehicle, payload and total, together with relative emissions.

It is clear that high payload vehicles perform unitary results much better than light payload ones. Those evaluations consider all life cycle energy and are based on the passenger loads or freight payloads used by all, considered by Radke. Several vehicles have been added to the analysis taking directly data by producers and by Strickland [31]. Radke and Strickland analyses have been improved by taking into consideration the amount of energy to produce vehicles, transportation infrastructure, and combustibles. Leisure vehicles have not been considered in this analysis because they have a marginal contribution to the global emissions.

Looking at global data it is possible to give the following interpretation of the result. Most people travel individually when possible. It has been also evidenced that that personal cars and trucks cause most of energy consumption and emissions. It is then fundamental to focus the attention on these systems verifying how they can be improved reducing their global impact without limiting their flexibility. 
Table 4 World transport energy use by mode (2004)

\begin{tabular}{lcc}
\hline Mode & Energy use (EJ) & Share $(\%)$ \\
\hline Passenger transport & 49.11 & 63.89 \\
Car & 34.20 & 44.49 \\
Busses & 4.76 & 6.19 \\
Air & 8.95 & 11.64 \\
Other personal transports & 1.20 & 1.56 \\
Passenger and freight transport & 1.19 & 1.55 \\
Rail & 1.19 & 1.55 \\
Freight transport & 26.57 & 34.56 \\
Heavy freight trucks & 12.48 & 16.24 \\
Medium freight trucks & 6.77 & 8.81 \\
Shipping & 7.32 & 9.52 \\
Total & 76.87 & 100.00 \\
\hline
\end{tabular}

Table 5 Emission factors and LHV for common fuels

\begin{tabular}{lll}
\hline & $\begin{array}{l}\text { Based on LHV kg } \\
\mathrm{CO}_{2} / \mathrm{GJ}\end{array}$ & $\mathrm{GJ} / 1$ \\
\hline Gasoline/petrol & 69.25 & 0.0344 \\
Kerosene & 71.45 & 0.0357 \\
Jet fuel & 70.72 & 0.0343 \\
Aviation gasoline & 69.11 & 0.0343 \\
Diesel & 74.01 & 0.0371 \\
LPG & 63.2 & 0.0249 \\
Natural gas* & 56.06 & 0.0350 \\
\hline
\end{tabular}

* GJ/standard cubic meter

Table 6 Life cycle energy needs by circulating vehicles

\begin{tabular}{lcc}
\hline Modes & Energy use (EJ) & Share $(\%)$ \\
\hline Car & 58.73 & 47.90 \\
Other personal transports & 1.84 & 1.50 \\
Busses & 8.33 & 6.79 \\
Trucks & 21.84 & 17.81 \\
Rail & 2.85 & 2.32 \\
Air & 14.45 & 11.79 \\
Ship & 14.58 & 11.89 \\
Total & 122.63 & 100.00 \\
\hline
\end{tabular}

\section{Ground transport in detail}

Impact of ground transportation

The present study has evidenced the criticality in terms of emissions and energetic need of ground transport. A milestone study on future development of transport sector has been produced by EU Transport GHG: Routes to $2050 \mathrm{II}$ project [32] founded by EU. This analysis takes into account

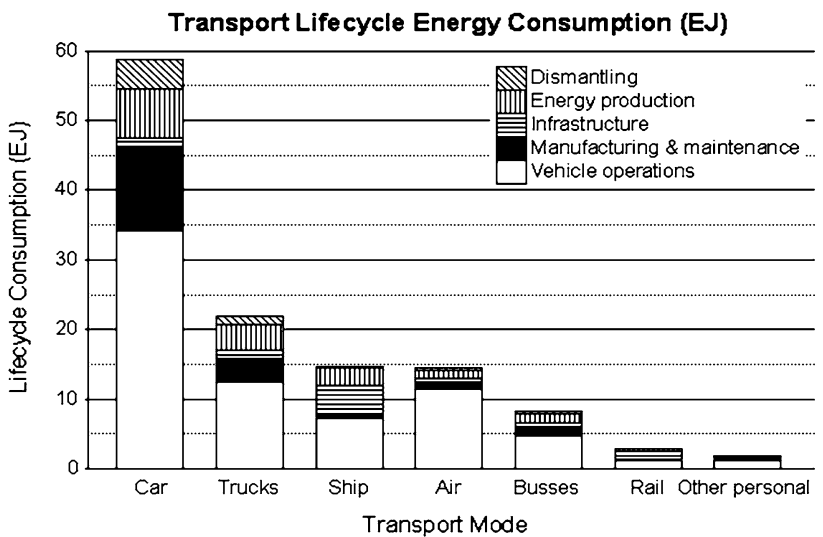

Fig. 8 Energetic requirements over the complete lifecycle of different transport modes

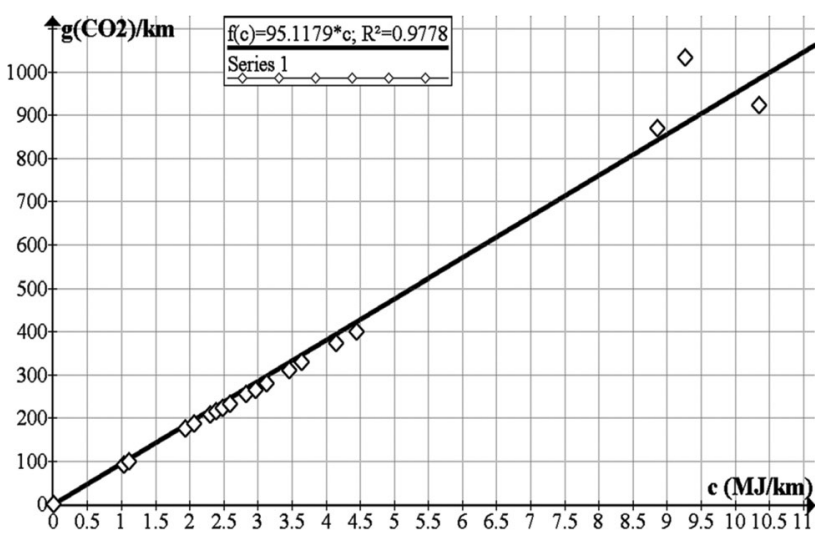

Fig. 9 Interpolation of $\mathrm{CO}_{2}$ emissions for common motor vehicles (ref. Table 6)

2010 standard transport situation vs. expected standards up to 2050. A synthetic representation is reported in Fig. 10.

This paper takes into account a different method that is the analysis of different kinds of vehicles. Focusing on specific benefit, which could be possible by an effective optimization of internal combustion vehicles that are the most critical in terms of both energy efficiency and emissions.

It has been considered the full vehicle taking into consideration the energy losses for moving the vehicle. A schema of the power train indicating the different losses is provided in Fig. 11.

Losses depend on the regime in which the vehicle operates (i.e., urban, highway or composite). The valuation of power needs can be performed by Eq. (14)

$\mathrm{Ex}_{\mathrm{vehicle}}=m_{\mathrm{tot}}\left(\operatorname{cg} v_{\mathrm{av}} t+\frac{1}{2} v_{\max }^{2}\right)+\frac{1}{2} C_{\mathrm{D}} A \rho_{\mathrm{air}} v_{\mathrm{av}}^{3} t$

It can be also possible to write the energy losses due to engine and to power train: 
Fig. 10 Expected growth in GHG emissions by transport mode (EU Transport GHG: Routes to 2050 II project)

Fig. 11 Losses in a ground vehicle
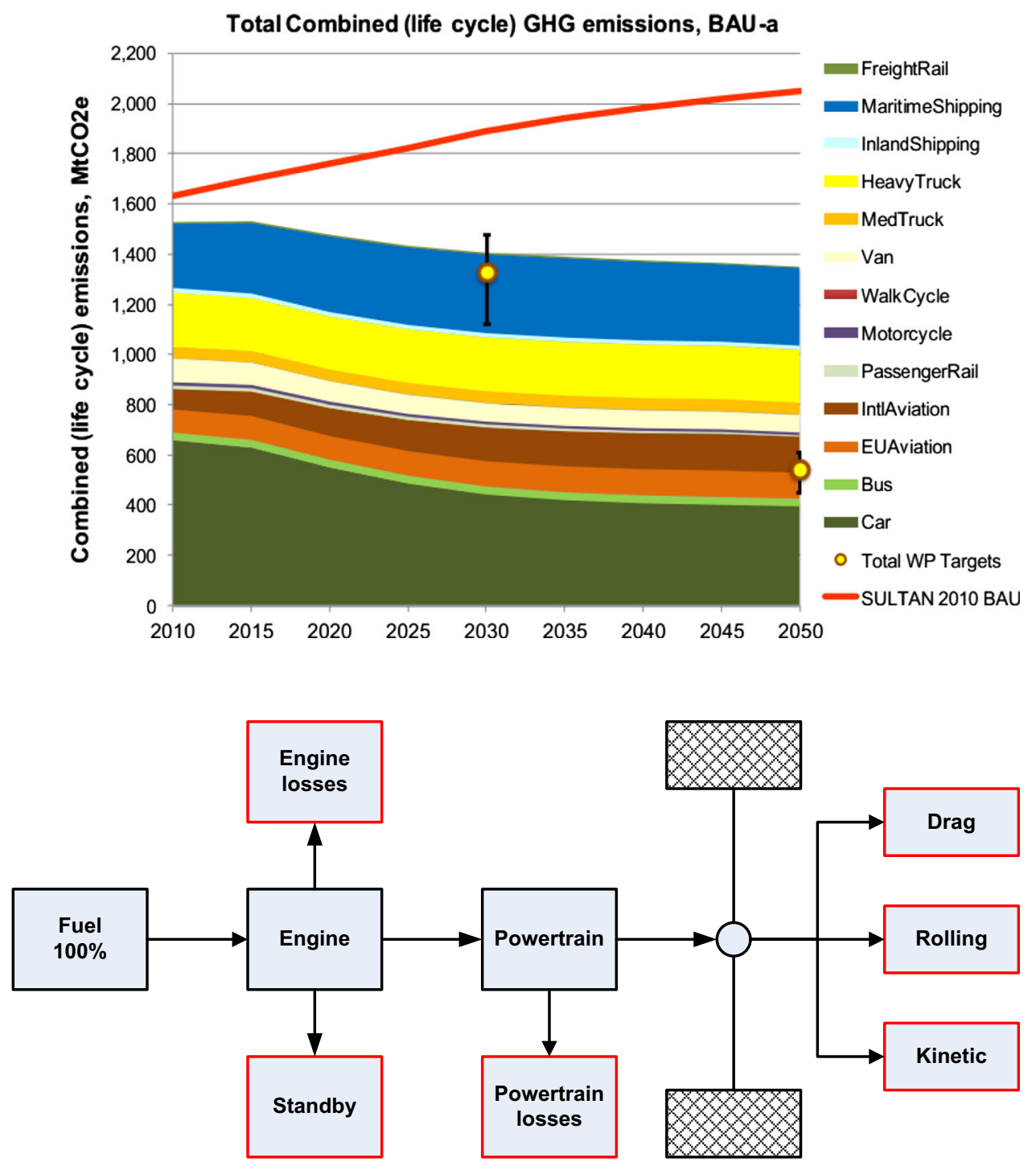

$\mathrm{Ex}_{\mathrm{vehicle}}=\mathrm{Ex}_{\text {fuel }}-L_{\text {engine }}-L_{\text {stanby }}-L_{\text {Powertrain }}$

According to Eqs. $(9,10,11)$ it is possible to perform a more sophisticated analysis about performances during operations of different vehicles in service conditions. In particular, cars, busses, and trucks have been considered, because they seem the less performing on an energetic and environmental point of view.

Preliminary calculations have been performed against Sovran and Bohn [33]. The results have been shown in Table 7. They show the full energetic value of the fuel and results appear perfectly in-line with Sovran and Bohn ones. Calculations have been performed for an average car, a truck, and a bus. A midsize car (1.3 ton), a heavy truck (40ton full payload), and a bus (16 ton) have been considered as preliminary references.

Table 7 allows making further analysis about optimization of the vehicle as it is.
In particular, data for different vehicles have been calculated iteratively according to the above calculation method obtaining results that can be applied to most vehicles. They are reported in "Appendix 4". The same vehicles considered in Table 3 have been considered even if they are listed in a different order.

Optimization of ground vehicles

Actual vehicle market seems to have reached a high degree of technological maturity. Most of vehicles have reached a standardized configuration with only minor upgrades possible and mostly relating the user interface, and some minor safety issues and some minor reductions in terms of energy consumption.

Bejan [34-38] has defined constructal theory, which is an effective method to understand the elementary logic of natural evolution and to allow design of more efficient 
Table 7 Reference values of energy consumption (\%) in city, highway, and composite regimes

\begin{tabular}{|c|c|c|c|c|c|c|c|c|c|c|}
\hline & & \multicolumn{3}{|l|}{ Car } & \multicolumn{3}{|l|}{ Truck } & \multicolumn{3}{|l|}{ Bus } \\
\hline & & City (\%) & $\mathrm{H}$ way $(\%)$ & Comp (\%) & City (\%) & $\mathrm{H}$ way $(\%)$ & Comp (\%) & City (\%) & $\mathrm{H}$ way $(\%)$ & Comp (\%) \\
\hline & Fuel Tank & 100.0 & 100.0 & 100.0 & 100.0 & 100.0 & 100.0 & 100.0 & 100.0 & 100.0 \\
\hline \multirow[t]{3}{*}{ Engine } & Engine & 74.0 & 70.0 & 72.0 & 65.0 & 60.0 & 62.5 & 62.0 & 60.0 & 61.0 \\
\hline & Standby & 6.0 & 0.5 & 3.3 & 5.0 & 1.0 & 3.0 & 8.0 & 1.5 & 4.8 \\
\hline & Output & 20.0 & 30.5 & 25.3 & 30.0 & 39.0 & 34.5 & 30.0 & 38.5 & 34.3 \\
\hline \multirow[t]{2}{*}{ Power train } & Driveline & 4.0 & 5.0 & 4.5 & 8.0 & 5.0 & 6.5 & 8.0 & 5.0 & 6.5 \\
\hline & Output & 16.0 & 25.5 & 20.8 & 22.0 & 34.0 & 28.0 & 22.0 & 33.5 & 27.8 \\
\hline \multirow[t]{3}{*}{ Operations } & Rolling & 4.4 & 9.0 & 6.3 & 4.4 & 11.1 & 7.7 & 4.4 & 12.1 & 8.3 \\
\hline & Drag & 2.9 & 12.9 & 6.2 & 4.4 & 18.7 & 11.6 & 3.6 & 18.6 & 11.1 \\
\hline & Kinetic & 8.7 & 3.7 & 8.2 & 11.0 & 2.6 & 6.8 & 14.0 & 2.8 & 8.4 \\
\hline
\end{tabular}

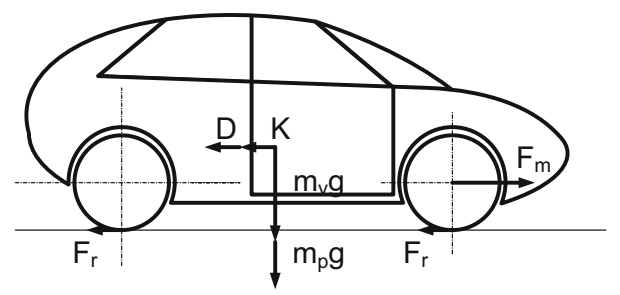

Fig. 12 Main forces acting on a ground vehicle during service

mechanical and thermodynamic systems. In particular, Bejan $[37,38]$ has argued that constructal law governs the natural evolution and motion efficiency.

Dumas [39, 40] and Trancossi [41, 42] have defined a technical design methodology for transport vehicle obtaining in the case of airships an effective optimization up to energy complete self-sufficiency by photovoltaic energy. This activity demonstrated that constructal law could produce surprising results in the optimization of transport vehicles.

Constructal can thus define effective guidelines for the future development of transport vehicles allowing also the definition of breakthrough configurations, which can produce major advantages if compared to the technological maturity scenario, in which today transport industry is operating.

Recent improvements on vehicles have focused on several modules but have not produced some fundamental results, which could be fundamental to produce an effective energetic benefit.

Optimization proposed actually is general, even if it opens the possibility of performing an effective analysis at vehicle level. In particular, it has taken into account the results in "Appendix 2", Fig. 14, for such vehicles. They express the influence of payload for different kinds of vehicles, which have obtained by Eq. 12 and 13 .

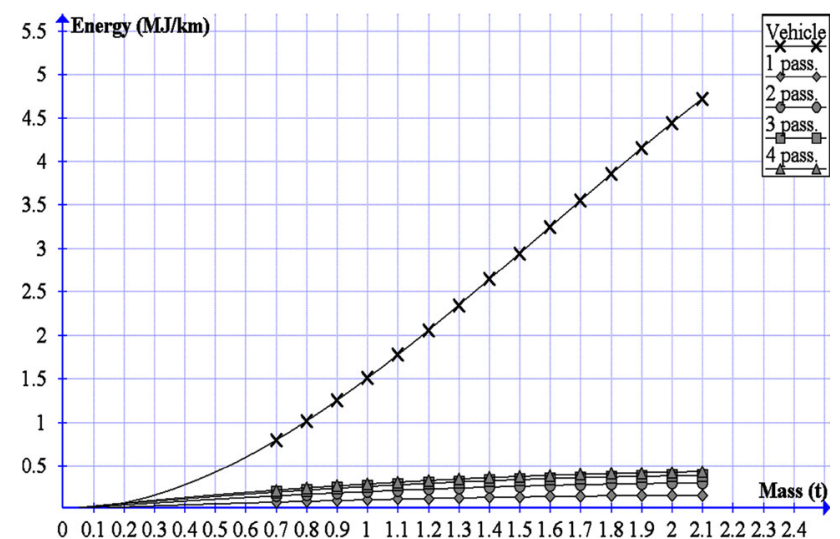

Fig. 13 Influence of the mass of a car on energy consumption and related consumption for passenger

The calculation schema is reported in Fig. 12, where Fr is the friction with ground, $\mathrm{D}$ is the aerodynamic drag, $\mathrm{K}$ is the term due to acceleration to the maximum velocity, and $\mathrm{Fm}$ is the force produced to the engine that moves the car.

For the considered vehicles, it is possible to make specific evaluations. They have been reported in "Appendix 4", Table 10. A more detailed evaluation based on the energy dissipation modes during service has been presented in "Appendix 4", Table 11. Data have been interpolated in the case of cars, which are the most impacting transport mode. They allow evaluating the influence of the mass of the vehicle on the energy consumption. These data originated by an effective calculation have been plotted in Fig. 13.

These results will allow focusing in design vehicles more effectively in terms of operational efficiency. It is clear that considering Eq. (12) and (13) the most important factors, on which an effective optimization could focus on weight and aerodynamics. In particular, focusing on light vehicles weight appears to be the most 
important element optimize in ground vehicles, while aerodynamics is most important for heavy vehicles. In particular, these directions of optimization presents an effective divergence with the vehicle development in the last 30 years, which has produced an effective increase in terms of mass, contrasting with the necessity of reducing energetic impact.

\section{Conclusions}

This paper has presented an effective analysis of energetic needs of different transport modes, starting from the pioneering work of Gabrielli and von Karman.

This activity has produced an effective comparison between different transport modes. Looking at global impacts in terms of energy consumption and emissions of GHG gas has focused on the necessity of producing advancements on higher impact transport modes. It has then focused on the problem of reducing the energy consumption of ground vehicle stating the preliminary basis for a future and effective constructal optimization of ground vehicles.

This paper aims then to be continued by an effective and future activity focused on an effective methodology for optimizing ground and ICE vehicles, and overcoming the actual technological maturity scenario of this industrial sector.

It appears clear that industrial strategy in the direction though standardization of components is producing a general reduction in terms of an effective minimization of costs but is producing much reduced advantages on an energetic point of view because of the consequent increase of the weight of vehicles, which accompanies this new technological scenario.

Acknowledgments A special thanks to Prof. Adrian Bejan for encouraging the activity for this paper. In particular, the main objective of this paper is to verify the algorithms for future performing of an effective energetic comparison of the MAAT cruiser/feeder airship transport with commonly used transport modes. The present work has been performed as part of Project MAAT । Multibody Advanced Airship for Transport I with ref. 285602, supported by European Union through the 7th Framework Program.

Open Access This article is distributed under the terms of the Creative Commons Attribution License which permits any use, distribution, and reproduction in any medium, provided the original author(s) and the source are credited.

\section{Appendix 1}

See Table 8 .

Table 8 Energy balance

\begin{tabular}{|c|c|c|c|c|c|c|}
\hline Service & $\begin{array}{l}\text { Propulsion } \\
\mathrm{MJ} / \mathrm{km}\end{array}$ & $\begin{array}{l}\text { Manufacturing and } \\
\text { maintenance } \mathrm{MJ} / \mathrm{km}\end{array}$ & $\begin{array}{l}\text { Infrastructure } \\
\mathrm{MJ} / \mathrm{km}\end{array}$ & $\begin{array}{l}\text { Energy } \\
\text { production } \mathrm{MJ} / \\
\mathrm{km}\end{array}$ & $\begin{array}{l}\text { Dismantling } \\
\mathrm{MJ} / \mathrm{km}\end{array}$ & $\begin{array}{l}\text { Total MJ/ } \\
\mathrm{km}\end{array}$ \\
\hline Human walking & 0.208443 & 0 & 0 & 0 & 0 & 0.208443 \\
\hline Airliner, 747-200-CCW Freight & 287.1104 & 13.54294 & 18.96012 & 28.44018 & 4.74003 & 352.7937 \\
\hline Airliner, 747-8, 10 lb/ft3 Freight & 448.4198 & 21.15188 & 29.61263 & 44.41894 & 7.403157 & 551.0064 \\
\hline Boeing 777-300ER & 390.8451 & 18.43609 & 25.81053 & 38.71579 & 6.452632 & 480.2602 \\
\hline Boeing 737-800 & 144.4899 & 6.815559 & 9.541783 & 14.31267 & 2.385446 & 177.5453 \\
\hline Airbus A320 & 165.2058 & 7.792726 & 10.90982 & 16.36472 & 2.727454 & 203.0005 \\
\hline Boeing 767-400ER & 273.1941 & 12.88651 & 18.04112 & 27.06168 & 4.51028 & 335.6937 \\
\hline Boeing 747-8 & 483.3383 & 22.79897 & 31.91856 & 47.87785 & 7.979641 & 593.9133 \\
\hline Airbus A340-600 & 439.7822 & 20.74445 & 29.04222 & 43.56334 & 7.260556 & 540.3928 \\
\hline Airbus A330-200 & 350.1383 & 16.51596 & 23.12234 & 34.68351 & 5.780586 & 430.2407 \\
\hline Concorde & 473 & 43.43878 & 67.57143 & 43.43878 & 15.20357 & 642.6526 \\
\hline Bombardier Q300 (DHC-8-300) & 63.4 & 2.990566 & 4.186792 & 6.280189 & 1.046698 & 77.90425 \\
\hline Eclipse 500 & 7.11 & 0.491758 & 0.245879 & 0.696657 & 0.172115 & 8.716409 \\
\hline $\begin{array}{l}\text { Diamond DA-42 Twin Star } \\
\text { (economy) }\end{array}$ & 4.22 & 0.291873 & 0.145937 & 0.413487 & 0.102156 & 5.173452 \\
\hline $\begin{array}{l}\text { Diamond DA-42 twin Star ( } 80 \% \\
\text { power) }\end{array}$ & 5.26 & 0.363804 & 0.181902 & 0.515389 & 0.127331 & 6.448427 \\
\hline Columbia 400 turbocharged $310 \mathrm{hp}$ & 5.98 & 0.413602 & 0.206801 & 0.585937 & 0.144761 & 7.331101 \\
\hline Columbia 400 turbocharged $310 \mathrm{hp}$ & 7.49 & 0.51804 & 0.25902 & 0.73389 & 0.181314 & 9.182265 \\
\hline Beechcraft duchess & 7.94 & 0.549164 & 0.274582 & 0.777983 & 0.192207 & 9.733937 \\
\hline
\end{tabular}


Table 8 continued

\begin{tabular}{|c|c|c|c|c|c|c|}
\hline Service & $\begin{array}{l}\text { Propulsion } \\
\mathrm{MJ} / \mathrm{km}\end{array}$ & $\begin{array}{l}\text { Manufacturing and } \\
\text { maintenance } \mathrm{MJ} / \mathrm{km}\end{array}$ & $\begin{array}{l}\text { Infrastructure } \\
\mathrm{MJ} / \mathrm{km}\end{array}$ & $\begin{array}{l}\text { Energy } \\
\text { production MJ/ } \\
\mathrm{km}\end{array}$ & $\begin{array}{l}\text { Dismantling } \\
\mathrm{MJ} / \mathrm{km}\end{array}$ & $\begin{array}{l}\text { Total MJ/ } \\
\mathrm{km}\end{array}$ \\
\hline Piper Navajo & 14.7 & 1.016715 & 0.508357 & 1.440346 & 0.35585 & 18.02127 \\
\hline Beechcraft King Air B-100 & 24.5 & 1.694524 & 0.847262 & 2.400576 & 0.593084 & 30.03545 \\
\hline Cessna 172 & 5.97 & 0.412911 & 0.206455 & 0.584957 & 0.144519 & 7.318841 \\
\hline Airship, 1936 & 663.461 & 31.29533 & 43.81346 & 65.72019 & 10.95337 & 815.2434 \\
\hline Zeppelin NT & 16.76395 & 0.790752 & 1.107053 & 1.66058 & 0.276763 & 20.5991 \\
\hline Airship GoodYear 1969 & 39.7 & 1.872642 & 2.621698 & 3.932547 & 0.655425 & 48.78231 \\
\hline Bicycle, touring & 0.055509 & 0.002618 & 0.003666 & 0.005499 & 0.000916 & 0.068208 \\
\hline Bicycle, racing & 0.080786 & 0.003811 & 0.005335 & 0.008002 & 0.001334 & 0.099268 \\
\hline Bicycle, touring & 0.084872 & 0.004003 & 0.005605 & 0.008407 & 0.001401 & 0.104289 \\
\hline Bicycle, touring & 0.126038 & 0.005945 & 0.008323 & 0.012485 & 0.002081 & 0.154872 \\
\hline Bicycle, electric cyclemotor & 0.325464 & 0.015352 & 0.021493 & 0.032239 & 0.005373 & 0.399922 \\
\hline 1982 New flyer trolley bus & 9.84 & 2.589474 & 1.035789 & 2.848421 & 0.906316 & 17.22 \\
\hline Bicycle, electric cyclemotor & 1.675 & 0.079009 & 0.110613 & 0.16592 & 0.027653 & 2.058196 \\
\hline $\begin{array}{l}2005 \text { (and later) new flyer low floor } \\
\text { trolley bus }\end{array}$ & 7.7 & 0.363208 & 0.508491 & 0.762736 & 0.127123 & 9.461557 \\
\hline $\begin{array}{l}\text { MCI 102DL3 diesel bus in } \\
\text { commuter service }\end{array}$ & 15 & 0.707547 & 0.990566 & 1.485849 & 0.247642 & 18.4316 \\
\hline MCI 102DL3 CNG/diesel bus & 18.6 & 0.877358 & 1.228302 & 1.842453 & 0.307075 & 22.85519 \\
\hline $\begin{array}{l}\text { Diesel bus in local and express } \\
\text { service }\end{array}$ & 24.3 & 1.146226 & 1.604717 & 2.407075 & 0.401179 & 29.8592 \\
\hline $\begin{array}{l}\text { Smart fortwo cdi ( } 0.8 \mathrm{~L} \text { diesel, } 40 \\
\text { hp, 6-speed) }\end{array}$ & 1.52 & 0.071698 & 0.100377 & 0.150566 & 0.025094 & 1.867736 \\
\hline $\begin{array}{l}\text { VW Golf TDI (1.9L diesel, } \\
\text { automatic) }\end{array}$ & 1.9 & 0.089623 & 0.125472 & 0.188208 & 0.031368 & 2.33467 \\
\hline $\begin{array}{l}\text { Smart fortwo cdi ( } 0.8 \mathrm{~L} \text { diesel, } 40 \\
\text { hp, 6-speed) }\end{array}$ & 1.44 & 0.067925 & 0.095094 & 0.142642 & 0.023774 & 1.769434 \\
\hline Corporate car 1990 & 2.73 & 0.128774 & 0.180283 & 0.270425 & 0.045071 & 3.354552 \\
\hline Porsche boxster $\mathrm{S}$ & 3.42 & 0.161321 & 0.225849 & 0.338774 & 0.056462 & 4.202406 \\
\hline Ford Explorer (4.6L V8) & 3.49 & 1.146124 & 0.103254 & 0.826036 & 0.401143 & 5.966558 \\
\hline Corporate car average fuel 1978 & 4.18 & 0.19717 & 0.276038 & 0.414057 & 0.069009 & 5.136274 \\
\hline Porsche carrera GT & 7.27 & 2.387485 & 0.215089 & 1.72071 & 0.83562 & 12.4289 \\
\hline Tesla roadster & 0.46 & 0.138754 & 0.015082 & 0.043738 & 0.048564 & 0.706138 \\
\hline Toyota prius & 1.58 & 0.548163 & 0.06449 & 0.328898 & 0.191857 & 2.713408 \\
\hline $\begin{array}{l}\text { Sikorsky S-76C ++ twin turbine } \\
\text { helicopter }\end{array}$ & 45.5 & 2.146226 & 3.004717 & 4.507075 & 0.751179 & 55.9092 \\
\hline Bell longranger IV & 25.5 & 1.20283 & 1.683962 & 2.525943 & 0.420991 & 31.33373 \\
\hline Griffon 2000TD hovercraft & 22.5 & 1.556196 & 0.778098 & 2.204611 & 0.544669 & 27.58357 \\
\hline Griffon $8000 \mathrm{TD}$ hovercraft & 101 & 11.88235 & 101 & 23.76471 & 4.158824 & 241.8059 \\
\hline $\begin{array}{l}\text { Siemens SD160 (42 ton } 24.82 \mathrm{~m} \\
\text { LRV }\end{array}$ & 11.6 & 0.84878 & 6.601626 & 3.960976 & 0.297073 & 23.30846 \\
\hline Siemens combino 28 ton $27 \mathrm{~m} \mathrm{LRV}$ & 5.51 & 0.403171 & 3.135772 & 1.881463 & 0.14111 & 11.07152 \\
\hline Siemens Combino 28 ton $27 \mathrm{~m} \mathrm{LRV}$ & 6.62 & 0.48439 & 3.76748 & 2.260488 & 0.169537 & 13.30189 \\
\hline Skytrain vancouver & 8.69 & 0.635854 & 4.945528 & 2.967317 & 0.222549 & 17.46125 \\
\hline London underground & 10.2 & 0.746341 & 5.804878 & 3.482927 & 0.26122 & 20.49537 \\
\hline $\begin{array}{l}\text { Suzuki GS500(motorcycle with } 0.5 \\
\text { L gasoline engine) }\end{array}$ & 1.25 & 0.433673 & 0.05102 & 0.260204 & 0.151786 & 2.146684 \\
\hline $\begin{array}{l}\text { Honda gold wing(motorcycle with } \\
1.8 \text { L 6-cylinder) }\end{array}$ & 2.3 & 0.797959 & 0.093878 & 0.478776 & 0.279286 & 3.949898 \\
\hline
\end{tabular}


Table 8 continued

\begin{tabular}{|c|c|c|c|c|c|c|}
\hline Service & $\begin{array}{l}\text { Propulsion } \\
\mathrm{MJ} / \mathrm{km}\end{array}$ & $\begin{array}{l}\text { Manufacturing and } \\
\text { maintenance } \mathrm{MJ} / \mathrm{km}\end{array}$ & $\begin{array}{l}\text { Infrastructure } \\
\mathrm{MJ} / \mathrm{km}\end{array}$ & $\begin{array}{l}\text { Energy } \\
\text { production } \mathrm{MJ} / \\
\mathrm{km}\end{array}$ & $\begin{array}{l}\text { Dismantling } \\
\mathrm{MJ} / \mathrm{km}\end{array}$ & $\begin{array}{l}\text { Total MJ/ } \\
\mathrm{km}\end{array}$ \\
\hline Wasp scooter & 1 & 0.346939 & 0.040816 & 0.208163 & 0.121429 & 1.717347 \\
\hline Tanker, VLCC Class & 12029.94 & 1415.287 & 12029.94 & 2830.574 & 495.3504 & 28801.09 \\
\hline Tanker, ULCC Class & 24812.6 & 2919.13 & 24812.6 & $5,838.259$ & $1,021.695$ & $59,404.29$ \\
\hline Cunard queen mary 2 ocean liner & 10000 & 1176.471 & 10000 & 2352.941 & 411.7647 & 23941.18 \\
\hline BC Ferries spirit class car ferries & 3063 & 360.3529 & 3063 & 720.7059 & 126.1235 & 7333.182 \\
\hline SeaBus & 302 & 35.52941 & 302 & 71.05882 & 12.43529 & 723.0235 \\
\hline Train, Avg Freight & 70 & 8.235294 & 70 & 16.47059 & 2.882353 & 167.5882 \\
\hline Train, dense freight (Coal) & 74 & 8.705882 & 74 & 17.41176 & 3.047059 & 177.1647 \\
\hline $\begin{array}{l}\text { TGV Duplex trainset }(300 \mathrm{~km} / \mathrm{h} \text { bi- } \\
\text { level, seats } 545)\end{array}$ & 64.8 & 7.623529 & 64.8 & 15.24706 & 2.668235 & 155.1388 \\
\hline $\begin{array}{l}\text { TGV Atlantique trainset }(300 \mathrm{~km} / \\
\mathrm{h} \text {, seats } 485)\end{array}$ & 47.52 & 5.590588 & 47.52 & 11.18118 & 1.956706 & 113.7685 \\
\hline $\begin{array}{l}\text { AVE } 300 \mathrm{~km} / \mathrm{h} \text { trainset on Madrid- } \\
\text { Seville line }\end{array}$ & 57.17 & 6.725882 & 57.17 & 13.45176 & 2.354059 & 136.8717 \\
\hline $\begin{array}{l}\text { TGV Paris Sud-Est trainset (TGV, } \\
270 \mathrm{~km} / \mathrm{h} \text {, seats } 368)\end{array}$ & 63.72 & 7.496471 & 63.72 & 14.99294 & 2.623765 & 152.5532 \\
\hline $\begin{array}{l}\text { ICE trainset }(280 \mathrm{~km} / \mathrm{h} \text {, seats } 645,12 \\
\text { coaches })\end{array}$ & 86.72 & 10.20235 & 86.72 & 20.40471 & 3.570824 & 207.6179 \\
\hline Colorado railcar & 79.8 & 5.839024 & 45.41463 & 27.24878 & 2.043659 & 160.3461 \\
\hline $\begin{array}{l}\text { Swedish railways X2000 } 200 \mathrm{~km} / \mathrm{h} \\
\text { tilting train }\end{array}$ & 42.7 & 5.023529 & 42.7 & 10.04706 & 1.758235 & 102.2288 \\
\hline $\begin{array}{l}\text { Danish railways Copenhagen- } \\
\text { Malmö }\end{array}$ & 24.1 & 2.835294 & 24.1 & 5.670588 & 0.992353 & 57.69824 \\
\hline $\begin{array}{l}\text { Swedish railways regina electric } \\
\text { multiple-unit train }\end{array}$ & 21.3 & 2.505882 & 21.3 & 5.011765 & 0.877059 & 50.99471 \\
\hline Colorado railcar & 34.9 & 4.105882 & 34.9 & 8.211765 & 1.437059 & 83.55471 \\
\hline $\begin{array}{l}\text { Swedish railwaysregina electric } \\
\text { multiple-unit train }\end{array}$ & 22.5 & 2.647059 & 22.5 & 5.294118 & 0.926471 & 53.86765 \\
\hline Truck, avg intercity & 45.52 & 5.355294 & 45.52 & 10.71059 & 1.874353 & 108.9802 \\
\hline
\end{tabular}

\section{Appendix 2}

See Figs. 14 and 15. 


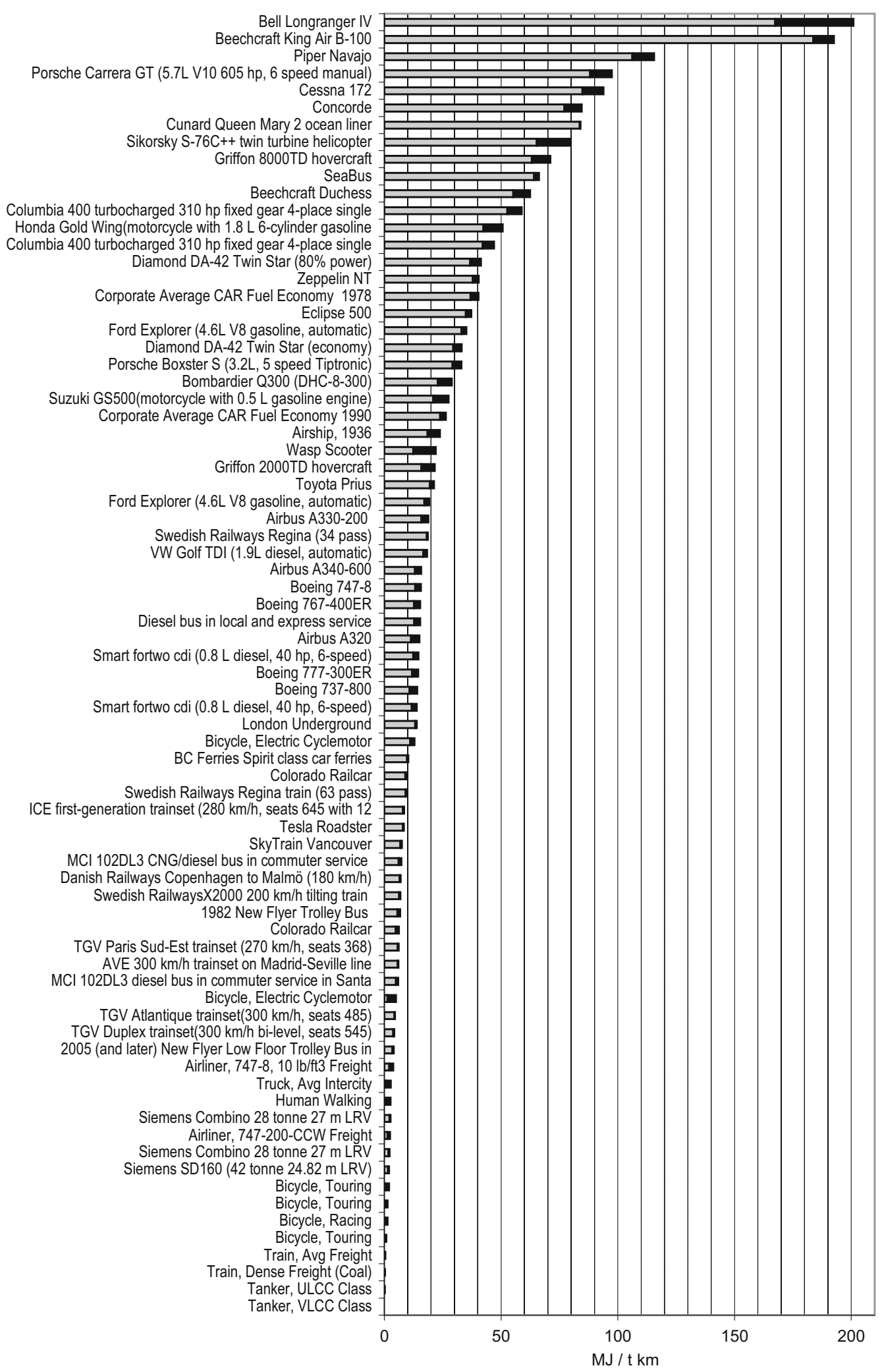

口Energy Required for Vehicle

Energy required for payload

Fig. 14 Cumulative evaluation of energy dissipation for vehicle movement and for freight movement $(\mathrm{MJ} / \mathrm{t} \mathrm{km})$ 


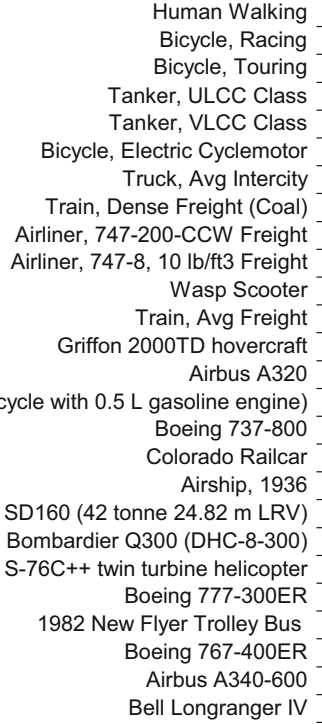

$\mathrm{MCl}$ 102DL3 diesel bus in commuter service Honda Gold Wing(motorcycle with $1.8 \mathrm{~L} 6$-cylinder gasoline)

Diesel bus in local and express service 2005 (and later) New Flyer Low Floor Trolley Bus Airbus A330-200

Smart fortwo cdi (0.8 L diesel, $40 \mathrm{hp}, 6$-speed) Siemens Combino 26 tonne LRV Siemens Combino 28 tonne $27 \mathrm{~m}$ LRV Boeing 747-8

Bicycle, Electric Cyclemoto Beechcraft Duchess

Porsche Boxster S (3.2L, 5 speed Tiptronic) Griffon 8000TD hovercraft

Ford Explorer (4.6L V8 gasoline, automatic) Diamond DA-42 Twin Star (80\% power)

Diamond DA-42 Twin Star (economy) Columbia 400 turbocharged $310 \mathrm{hp}$ fixed gear 4-place single Columbia 400 turbocharged $310 \mathrm{hp}$ fixed gear 4-place single

Porsche Carrera GT (5.7L V10 605 hp, 6 speed manual) Cessna 172

Corporate Average CAR Fuel Economy 1990 VW Golf TDI (1.9L diesel, automatic) Colorado Railcar Concorde

TGV Duplex trainset(300 km/h bi-level, seats 545 Corporate Average CAR Fuel Economy 1978

Toyota Prius Piper Navajo

SkyTrain Vancouver

Swedish RailwaysX2000 200 km/h tilting train TGV Paris Sud-Est trainset $(270 \mathrm{~km} / \mathrm{h}$, seats 368 )

TGV Atlantique trainset $(300 \mathrm{~km} / \mathrm{h}$, seats 485$)$

Zeppelin NT Eclipse 500

Danish Railways Copenhagen to Malmö (180 km/h)

Ford Explorer (4.6L V8 gasoline, automatic) BC Ferries Spirit class car ferrie

AVE $300 \mathrm{~km} / \mathrm{h}$ trainset on Madrid-Seville line ICE first-generation trainset $(280 \mathrm{~km} / \mathrm{h}$, seats 645 with 12 London Underground Beechcraft King Air B-100 Swedish Railways Regina train (63 pass) Tesla Roadster SeaBus Swedish Railways Regina (34 pass) Cunard Queen Mary 2 ocean liner

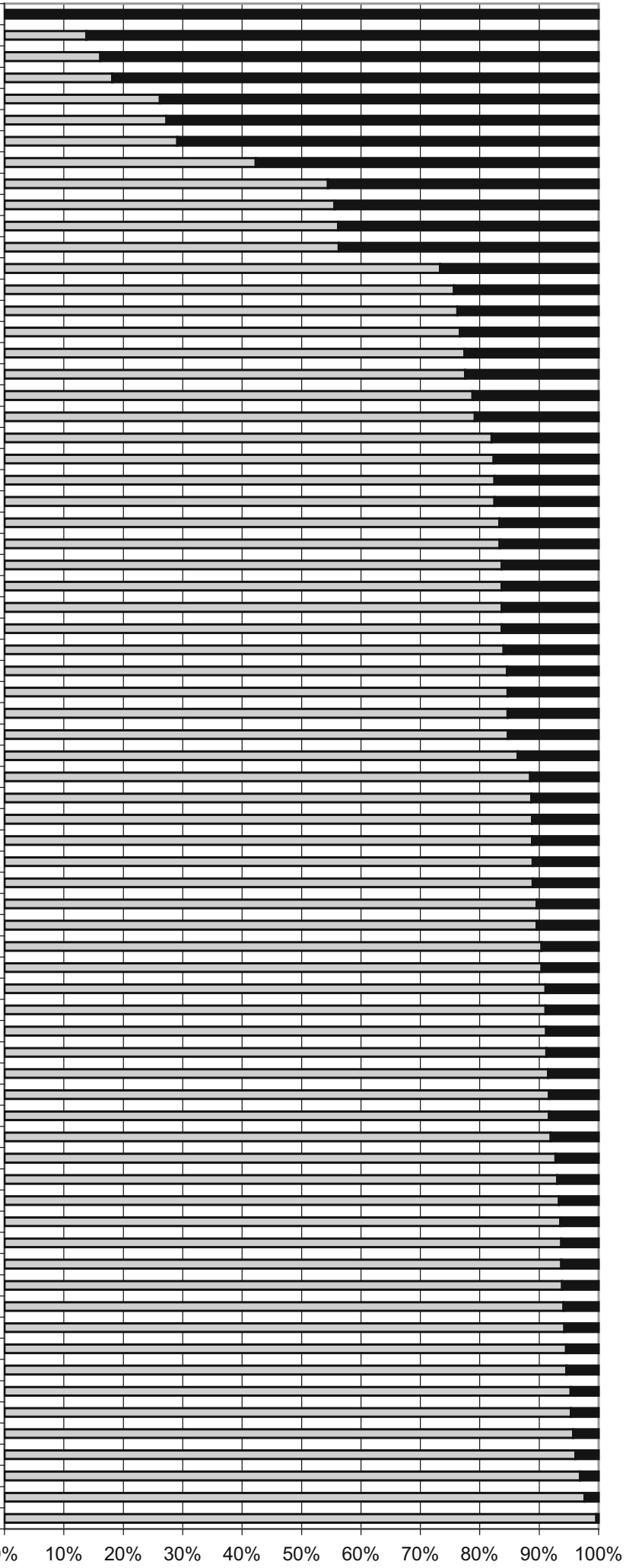

DEnergy Required for Vehicle Energy required for payload

Fig. 15 Evaluation of energy dissipation for vehicle movement and for freight movement (\%) 


\section{Appendix 3}

See Table 9.

Table 9 Energy consumption for unit of load and emissions

\begin{tabular}{|c|c|c|c|c|c|c|c|c|c|c|c|}
\hline \multirow[t]{2}{*}{ Service } & \multirow{2}{*}{$\begin{array}{l}\begin{array}{l}\text { Energy } \\
\text { consumption }\end{array} \\
\text { Total } \\
\text { MJ/km }\end{array}$} & \multirow{2}{*}{$\begin{array}{l}\text { Emissions } \\
\text { Total } \\
\mathrm{Kg}\left(\mathrm{CO}_{2}\right) / \\
\mathrm{km}\end{array}$} & \multicolumn{3}{|l|}{ Mass } & \multicolumn{3}{|c|}{$\begin{array}{l}\text { Energy consumptionper } \\
\text { unit of load }\end{array}$} & \multicolumn{3}{|c|}{ Emissions per unit of load } \\
\hline & & & $\begin{array}{l}\text { Vehicle } \\
\mathrm{t}\end{array}$ & $\begin{array}{l}\text { Payload } \\
\mathrm{t}\end{array}$ & $\begin{array}{l}\text { Total } \\
\mathrm{T}\end{array}$ & $\begin{array}{l}\text { Vehicle } \\
\mathrm{MJ} / \mathrm{t} \\
\mathrm{km}\end{array}$ & $\begin{array}{l}\text { Payload } \\
\mathrm{MJ} / \mathrm{t} \\
\mathrm{km}\end{array}$ & $\begin{array}{l}\text { Total } \\
\mathrm{MJ} / \mathrm{t} \\
\mathrm{km}\end{array}$ & $\begin{array}{l}\text { Vehicle } \\
\mathrm{g}\left(\mathrm{CO}_{2}\right) / \\
\mathrm{t} \mathrm{km}\end{array}$ & $\begin{array}{l}\text { Payload } \\
\mathrm{g}\left(\mathrm{CO}_{2}\right) / \\
\mathrm{t} \mathrm{km}\end{array}$ & $\begin{array}{l}\text { Total } \\
\mathrm{g}\left(\mathrm{CO}_{2}\right) / \\
\mathrm{t} \mathrm{km}\end{array}$ \\
\hline Tanker, VLCC class & 28801.086 & 2739.499 & 76000 & 214500 & 290500 & 0.035 & 0.099 & 0.134 & 0.003 & 0.009 & 0.013 \\
\hline Tanker, ULCC class & 59404.287 & 5650.411 & 76000 & 343200 & 419200 & 0.031 & 0.142 & 0.173 & 0.003 & 0.013 & 0.016 \\
\hline $\begin{array}{l}\text { Train, Dense freight } \\
\text { (Coal) }\end{array}$ & 177.165 & 16.852 & 550.00 & 750 & 1300 & 0.100 & 0.136 & 0.236 & 0.010 & 0.013 & 0.022 \\
\hline Train, avg freight & 167.588 & 15.941 & 550.00 & 427 & 977.5 & 0.221 & 0.171 & 0.392 & 0.021 & 0.016 & 0.037 \\
\hline Bicycle, touring & 0.068 & 0.006 & 0.02 & 0.08 & 0.10 & 0.178 & 0.696 & 0.874 & 0.017 & 0.066 & 0.083 \\
\hline Bicycle, racing & 0.099 & 0.009 & 0.01 & 0.08 & 0.09 & 0.183 & 1.141 & 1.324 & 0.017 & 0.109 & 0.126 \\
\hline Bicycle, touring & 0.104 & 0.010 & 0.02 & 0.08 & 0.09 & 0.216 & 1.121 & 1.337 & 0.021 & 0.107 & 0.127 \\
\hline Bicycle, touring & 0.155 & 0.015 & 0.02 & 0.08 & 0.09 & 0.320 & 1.665 & 1.986 & 0.030 & 0.158 & 0.189 \\
\hline $\begin{array}{l}\text { Siemens SD160 (42 ton } \\
24.82 \mathrm{~m} \mathrm{LRV)}\end{array}$ & 23.308 & 2.217 & 42.00 & 11.31 & 53.31 & 1.62 & 0.44 & 2.06 & 0.154 & 0.042 & 0.196 \\
\hline $\begin{array}{l}\text { Siemens Combino } 28 \text { ton } \\
27 \text { m LRV }\end{array}$ & 11.072 & 1.053 & 28.00 & 5.07 & 33.07 & 1.85 & 0.33 & 2.18 & 0.176 & 0.032 & 0.208 \\
\hline $\begin{array}{l}\text { Airliner, 747-200-CCW } \\
\text { Freight }\end{array}$ & 352.794 & 33.557 & 172.00 & 144 & 316.00 & 1.33 & 1.12 & 2.45 & 0.127 & 0.106 & 0.233 \\
\hline $\begin{array}{l}\text { Siemens Combino } 28 \text { ton } \\
27 \text { m LRV }\end{array}$ & 13.302 & 1.265 & 28.00 & 5.07 & 33.07 & 2.22 & 0.40 & 2.62 & 0.211 & 0.038 & 0.250 \\
\hline Human walking & 0.208 & 0.020 & 0.00 & 0.08 & 0.08 & 0.00 & 2.67 & 2.67 & 0.000 & 0.254 & 0.254 \\
\hline Truck, avg intercity & 108.980 & 10.366 & 16.00 & 39.00 & 55.00 & 0.81 & 1.98 & 2.79 & 0.077 & 0.188 & 0.266 \\
\hline $\begin{array}{l}\text { Airliner, 747-8, } 10 \mathrm{lb} / \mathrm{ft} 3 \\
\text { freight }\end{array}$ & 551.006 & 52.411 & 180.00 & 144 & 324.00 & 2.13 & 1.70 & 3.83 & 0.202 & 0.162 & 0.364 \\
\hline $\begin{array}{l}2005 \text { New flyer low floor } \\
\text { trolley bus }\end{array}$ & 9.462 & 0.900 & 12.00 & 2.34 & 14.34 & 3.38 & 0.66 & 4.04 & 0.322 & 0.063 & 0.385 \\
\hline $\begin{array}{l}\text { TGV } \\
\text { Duplex trainset }(300 \mathrm{~km} / \\
\text { h bi-level, seats } 545)\end{array}$ & 155.139 & 14.756 & 400.00 & 37.06 & 437.06 & 3.83 & 0.35 & 4.19 & 0.364 & 0.034 & 0.398 \\
\hline $\begin{array}{l}\text { TGV Atlantique } \\
\text { trainset }(300 \mathrm{~km} / \mathrm{h} \text {, seats } \\
485)\end{array}$ & 113.768 & 10.821 & 360.00 & 24.74 & 384.74 & 4.30 & 0.30 & 4.60 & 0.409 & 0.028 & 0.437 \\
\hline $\begin{array}{l}\text { Bicycle, electric } \\
\text { cyclemotor }\end{array}$ & 0.400 & 0.038 & 0.03 & 0.08 & 0.11 & 1.36 & 3.64 & 5.00 & 0.130 & 0.346 & 0.475 \\
\hline $\begin{array}{l}\text { MCI 102DL3 diesel bus in } \\
\text { commuter service }\end{array}$ & 18.432 & 1.753 & 16.00 & 3.12 & 19.12 & 4.94 & 0.96 & 5.91 & 0.470 & 0.092 & 0.562 \\
\hline $\begin{array}{l}\text { AVE } 300 \mathrm{~km} / \mathrm{h} \text { trainset on } \\
\text { Madrid-Seville line }\end{array}$ & 136.872 & 13.019 & 392.00 & 22.61 & 414.61 & 5.72 & 0.33 & 6.05 & 0.544 & 0.031 & 0.576 \\
\hline $\begin{array}{l}\text { TGV Paris Sud-Est } \\
\text { trainset }(270 \mathrm{~km} / \\
\text { h, seats } 368)\end{array}$ & 152.553 & 14.511 & 350.00 & 24.99 & 374.99 & 5.70 & 0.41 & 6.10 & 0.542 & 0.039 & 0.581 \\
\hline Colorado railcar & 160.346 & 15.252 & 87.50 & 25.50 & 113.00 & 4.87 & 1.42 & 6.29 & 0.463 & 0.135 & 0.598 \\
\hline 1982 New flyer trolley bus & 17.220 & 1.638 & 12.00 & 2.55 & 14.55 & 5.57 & 1.18 & 6.75 & 0.530 & 0.113 & 0.642 \\
\hline $\begin{array}{l}\text { Swedish railways } \\
\text { X2000 } 200 \mathrm{~km} / \mathrm{h} \text { tilting } \\
\text { train }\end{array}$ & 102.229 & 9.724 & 200.00 & 14.96 & 214.96 & 6.36 & 0.48 & 6.83 & 0.605 & 0.045 & 0.650 \\
\hline $\begin{array}{l}\text { Danish railways }(180 \mathrm{~km} / \\
\text { h) }\end{array}$ & 57.698 & 5.488 & 126.00 & 8.25 & 134.25 & 6.57 & 0.43 & 7.00 & 0.625 & 0.041 & 0.666 \\
\hline $\begin{array}{l}\text { MCI 102DL3 CNG/diesel } \\
\text { bus in commuter service }\end{array}$ & 22.855 & 2.174 & 16.00 & 3.12 & 19.12 & 6.13 & 1.20 & 7.33 & 0.583 & 0.114 & 0.697 \\
\hline SkyTrain vancouver & 17.461 & 1.661 & 30.00 & 2.34 & 32.34 & 6.92 & 0.54 & 7.46 & 0.658 & 0.051 & 0.710 \\
\hline
\end{tabular}


Table 9 continued

\begin{tabular}{|c|c|c|c|c|c|c|c|c|c|c|c|}
\hline \multirow[t]{2}{*}{ Service } & \multirow{2}{*}{$\begin{array}{l}\begin{array}{l}\text { Energy } \\
\text { consumption }\end{array} \\
\text { Total } \\
\text { MJ/km }\end{array}$} & \multirow{2}{*}{$\begin{array}{l}\text { Emissions } \\
\text { Total } \\
\mathrm{Kg}\left(\mathrm{CO}_{2}\right) / \\
\mathrm{km}\end{array}$} & \multicolumn{3}{|l|}{ Mass } & \multicolumn{3}{|c|}{$\begin{array}{l}\text { Energy consumptionper unit of } \\
\text { load }\end{array}$} & \multicolumn{3}{|c|}{ Emissions per unit of load } \\
\hline & & & $\begin{array}{l}\text { Vehicle } \\
\mathrm{t}\end{array}$ & $\begin{array}{l}\text { Payload } \\
\text { t }\end{array}$ & $\begin{array}{l}\text { Total } \\
\mathrm{T}\end{array}$ & $\begin{array}{l}\text { Vehicle } \\
\mathrm{MJ} / \mathrm{t} \mathrm{km}\end{array}$ & $\begin{array}{l}\text { Payload } \\
\mathrm{MJ} / \mathrm{t} \mathrm{km}\end{array}$ & $\begin{array}{l}\text { Total } \\
\mathrm{MJ} / \mathrm{t} \\
\mathrm{km}\end{array}$ & $\begin{array}{l}\text { Vehicle } \\
\mathrm{g}\left(\mathrm{CO}_{2}\right) / \mathrm{t} \\
\mathrm{km}\end{array}$ & $\begin{array}{l}\text { Payload } \\
\mathrm{g}\left(\mathrm{CO}_{2}\right) / \mathrm{t} \\
\mathrm{km}\end{array}$ & $\begin{array}{l}\text { Total } \\
\mathrm{g}\left(\mathrm{CO}_{2}\right) / \mathrm{t} \\
\mathrm{km}\end{array}$ \\
\hline Tesla roadster & 0.706 & 0.067 & 2.10 & 0.09 & 2.19 & 7.98 & 0.32 & 8.31 & 0.759 & 0.031 & 0.790 \\
\hline $\begin{array}{l}\text { ICE trainset }(280 \mathrm{~km} / \mathrm{h}, \\
\text { seats } 645,12 \text { coaches })\end{array}$ & 207.618 & 19.748 & 430.00 & 24.65 & 454.65 & 7.97 & 0.46 & 8.42 & 0.758 & 0.043 & 0.801 \\
\hline $\begin{array}{l}\text { Swedish railways } \\
\text { Regina train ( } 63 \text { pass) }\end{array}$ & 50.995 & 4.851 & 120.00 & 5.36 & 125.36 & 9.12 & 0.41 & 9.52 & 0.867 & 0.039 & 0.906 \\
\hline Colorado railcar & 83.555 & 7.948 & 87.50 & 8.50 & 96.00 & 8.96 & 0.87 & 9.83 & 0.852 & 0.083 & 0.935 \\
\hline $\begin{array}{l}\text { BC ferries spirit class car } \\
\text { ferries }\end{array}$ & 7333.182 & 697.517 & 11681 & 712.50 & 12393.5 & 9.70 & 0.59 & 10.29 & 0.923 & 0.056 & 0.979 \\
\hline $\begin{array}{l}\text { Bicycle, electric } \\
\text { cyclemotor }\end{array}$ & 2.058 & 0.196 & 1.02 & 0.16 & 1.18 & 11.11 & 1.75 & 12.86 & 1.057 & 0.167 & 1.224 \\
\hline London underground & 20.495 & 1.949 & 30.00 & 1.48 & 31.48 & 13.18 & 0.65 & 13.83 & 1.254 & 0.062 & 1.315 \\
\hline $\begin{array}{l}\text { Smart fortwo cdi }(0.8 \mathrm{~L} \\
\text { diesel, } 40 \mathrm{hp}, 6 \text {-speed })\end{array}$ & 1.769 & 0.168 & 0.70 & 0.13 & 0.83 & 11.74 & 2.14 & 13.88 & 1.117 & 0.203 & 1.320 \\
\hline Boeing 737-800 & 177.545 & 16.888 & 41.40 & 12.60 & 54.00 & 10.80 & 3.29 & 14.09 & 1.028 & 0.313 & 1.340 \\
\hline Boeing 777-300ER & 480.260 & 45.681 & 155.00 & 33.25 & 188.25 & 11.89 & 2.55 & 14.44 & 1.131 & 0.243 & 1.374 \\
\hline Airbus A320 & 203.001 & 19.309 & 42.00 & 13.50 & 55.50 & 12.39 & 2.26 & 14.65 & 1.082 & 0.348 & 1.430 \\
\hline $\begin{array}{l}\text { Diesel bus in local and } \\
\text { express service }\end{array}$ & 29.859 & 2.840 & 10.00 & 1.95 & 11.95 & 11.38 & 3.66 & 15.04 & 1.219 & 0.238 & 1.456 \\
\hline Boeing 767-400ER & 335.694 & 31.930 & 103.00 & 21.85 & 124.85 & 12.67 & 2.69 & 15.36 & 1.206 & 0.256 & 1.461 \\
\hline Boeing 747-8 & 593.913 & 56.492 & 211.00 & 38.00 & 249.00 & 13.24 & 2.39 & 15.63 & 1.260 & 0.227 & 1.487 \\
\hline Airbus A340-600 & 540.393 & 51.401 & 170.40 & 34.20 & 204.60 & 13.16 & 2.64 & 15.80 & 1.252 & 0.251 & 1.503 \\
\hline $\begin{array}{l}\text { VW Golf TDI } \\
\text { (1.9L diesel, automatic) }\end{array}$ & 2.335 & 0.222 & 1.30 & 0.13 & 1.43 & 16.68 & 1.64 & 18.31 & 1.586 & 0.156 & 1.742 \\
\hline $\begin{array}{l}\text { Swedish railways regina } \\
\text { (34 pass) }\end{array}$ & 53.868 & 5.124 & 120.00 & 2.89 & 122.89 & 18.20 & 0.44 & 18.64 & 1.731 & 0.042 & 1.773 \\
\hline Airbus A330-200 & 430.241 & 40.924 & 120.00 & 22.80 & 142.80 & 15.86 & 3.01 & 18.87 & 1.508 & 0.287 & 1.795 \\
\hline $\begin{array}{l}\text { Ford explorer (4.6L V8, } \\
\text { automatic) }\end{array}$ & 6.562 & 0.624 & 2.70 & 0.34 & 3.04 & 17.14 & 2.16 & 19.30 & 1.630 & 0.205 & 1.836 \\
\hline Toyota prius & 2.713 & 0.258 & 1.40 & 0.13 & 1.53 & 19.51 & 1.78 & 21.28 & 1.855 & 0.169 & 2.024 \\
\hline $\begin{array}{l}\text { Griffon 2000TD } \\
\text { hovercraft }\end{array}$ & 27.584 & 2.624 & 3.50 & 1.28 & 4.78 & 15.86 & 5.78 & 21.63 & 1.508 & 0.549 & 2.058 \\
\hline Wasp scooter & 1.717 & 0.163 & 0.10 & 0.08 & 0.18 & 12.37 & 9.65 & 22.02 & 1.177 & 0.918 & 2.094 \\
\hline Airship, 1936 & 815.243 & 77.544 & 118.00 & 34.20 & 152.20 & 18.48 & 5.36 & 23.84 & 1.758 & 0.509 & 2.267 \\
\hline $\begin{array}{l}\text { Corporate average Car } \\
\text { fuel economy } 1990\end{array}$ & 3.355 & 0.319 & 1.30 & 0.13 & 1.43 & 23.96 & 2.35 & 26.31 & 2.279 & 0.224 & 2.503 \\
\hline $\begin{array}{l}\text { Suzuki GS500 } \\
\text { (motorcycle } 0.5 \mathrm{~L} \text { ) }\end{array}$ & 2.147 & 0.204 & 0.25 & 0.08 & 0.33 & 20.98 & 6.54 & 27.52 & 1.995 & 0.623 & 2.618 \\
\hline $\begin{array}{l}\text { Bombardier Q300 (DHC- } \\
\text { 8-300) }\end{array}$ & 77.904 & 7.410 & 10.25 & 2.70 & 12.95 & 22.84 & 6.02 & 28.85 & 2.172 & 0.572 & 2.744 \\
\hline $\begin{array}{l}\text { Porsche Boxster S (3.2L, } 5 \\
\text { speed Tiptronic) }\end{array}$ & 4.202 & 0.400 & 1.00 & 0.13 & 1.13 & 29.23 & 3.73 & 32.96 & 2.781 & 0.355 & 3.135 \\
\hline $\begin{array}{l}\text { Diamond DA-42 twin star } \\
\text { (economy) }\end{array}$ & 5.173 & 0.492 & 1.25 & 0.16 & 1.41 & 29.49 & 3.68 & 33.16 & 2.805 & 0.350 & 3.154 \\
\hline $\begin{array}{l}\text { Ford Explorer (4.6L V8 } \\
\text { gasoline, automatic) }\end{array}$ & 5.967 & 0.568 & 2.70 & 0.17 & 2.87 & 33.02 & 2.08 & 35.10 & 3.141 & 0.198 & 3.338 \\
\hline Eclipse 500 & 8.716 & 0.829 & 3.50 & 0.23 & 3.73 & 34.92 & 2.33 & 37.25 & 3.321 & 0.222 & 3.543 \\
\hline $\begin{array}{l}\text { Corporate average car fuel } \\
\text { economy } 1978\end{array}$ & 5.136 & 0.489 & 1.40 & 0.13 & 1.53 & 36.92 & 3.36 & 40.28 & 3.512 & 0.320 & 3.832 \\
\hline Zeppelin NT & 20.599 & 1.959 & 7.60 & 0.51 & 8.11 & 37.85 & 2.54 & 40.39 & 3.600 & 0.242 & 3.842 \\
\hline $\begin{array}{l}\text { Diamond DA-42 twin star } \\
\text { ( } 80 \% \text { power) }\end{array}$ & 6.448 & 0.613 & 1.25 & 0.16 & 1.41 & 36.75 & 4.59 & 41.34 & 3.496 & 0.436 & 3.932 \\
\hline $\begin{array}{l}\text { Columbia } 400 \\
\text { turbocharged } 310 \mathrm{hp}\end{array}$ & 7.331 & 0.697 & 1.34 & 0.16 & 1.50 & 42.09 & 4.90 & 46.99 & 4.004 & 0.466 & 4.470 \\
\hline
\end{tabular}


Table 9 continued

\begin{tabular}{|c|c|c|c|c|c|c|c|c|c|c|c|}
\hline \multirow[t]{2}{*}{ Service } & \multirow{2}{*}{$\begin{array}{l}\begin{array}{l}\text { Energy } \\
\text { consumption }\end{array} \\
\text { Total } \\
\mathrm{MJ} / \mathrm{km}\end{array}$} & \multirow{2}{*}{$\begin{array}{l}\text { Emissions } \\
\text { Total } \\
\mathrm{Kg}\left(\mathrm{CO}_{2}\right) / \\
\mathrm{km}\end{array}$} & \multicolumn{3}{|l|}{ Mass } & \multicolumn{3}{|c|}{$\begin{array}{l}\text { Energy consumptionper unit of } \\
\text { load }\end{array}$} & \multicolumn{3}{|c|}{ Emissions per unit of load } \\
\hline & & & $\begin{array}{l}\text { Vehicle } \\
\mathrm{t}\end{array}$ & $\begin{array}{l}\text { Payload } \\
\mathrm{t}\end{array}$ & $\begin{array}{l}\text { Total } \\
\mathrm{T}\end{array}$ & $\begin{array}{l}\text { Vehicle } \\
\mathrm{MJ} / \mathrm{t} \mathrm{km}\end{array}$ & $\begin{array}{l}\text { Payload } \\
\mathrm{MJ} / \mathrm{t} \mathrm{km}\end{array}$ & $\begin{array}{l}\text { Total } \\
\mathrm{MJ} / \mathrm{t} \\
\mathrm{km}\end{array}$ & $\begin{array}{l}\text { Vehicle } \\
\mathrm{g}\left(\mathrm{CO}_{2}\right) / \mathrm{t} \\
\mathrm{km}\end{array}$ & $\begin{array}{l}\text { Payload } \\
\mathrm{g}\left(\mathrm{CO}_{2}\right) / \mathrm{t} \\
\mathrm{km}\end{array}$ & $\begin{array}{l}\text { Total } \\
\mathrm{g}\left(\mathrm{CO}_{2}\right) / \mathrm{t} \\
\mathrm{km}\end{array}$ \\
\hline $\begin{array}{l}\text { Honda Goldwing } \\
\quad \text { (motorcycle } 1.8 \mathrm{~L} \text { ) }\end{array}$ & 3.950 & 0.376 & 0.40 & 0.08 & 0.48 & 42.38 & 8.26 & 50.64 & 4.031 & 0.786 & 4.817 \\
\hline Beechcraft Duchess & 9.734 & 0.926 & 1.20 & 0.16 & 1.36 & 52.72 & 6.14 & 58.86 & 5.252 & 0.683 & 5.935 \\
\hline SeaBus & 723.024 & 68.772 & 341.00 & 10.92 & 351.92 & 55.22 & 7.18 & 62.40 & 6.102 & 0.195 & 6.298 \\
\hline $\begin{array}{l}\text { Griffon } 8000 \mathrm{TD} \\
\text { hovercraft }\end{array}$ & 241.806 & 23.000 & 27.00 & 3.40 & 30.40 & 64.16 & 2.05 & 66.21 & 6.008 & 0.757 & 6.765 \\
\hline $\begin{array}{l}\text { Sikorsky S-76C ++ twin } \\
\text { turbine helicopter }\end{array}$ & 55.909 & 5.318 & 3.20 & 0.70 & 3.90 & 63.17 & 7.95 & 71.12 & 6.213 & 1.363 & 7.575 \\
\hline $\begin{array}{l}\text { Cunard Queen Mary } 2 \\
\text { ocean liner }\end{array}$ & 23941.176 & 2277.234 & 76000 & 285 & 76285 & 65.31 & 14.33 & 79.64 & 7.960 & 0.030 & 7.990 \\
\hline Concorde & 642.653 & 61.128 & 78.70 & 7.60 & 86.30 & 83.69 & 0.31 & 84.00 & 7.335 & 0.708 & 8.043 \\
\hline Cessna 172 & 7.319 & 0.696 & 0.74 & 0.08 & 0.81 & 77.11 & 7.45 & 84.56 & 8.070 & 0.855 & 8.925 \\
\hline $\begin{array}{l}\text { Porsche Carrera GT }(5.7 \mathrm{~L} \\
\text { V10 } 605 \mathrm{hp})\end{array}$ & 12.429 & 1.182 & 1.20 & 0.13 & 1.33 & 84.84 & 8.99 & 93.83 & 8.382 & 0.891 & 9.272 \\
\hline Piper Navajo & 18.021 & 1.714 & 1.78 & 0.16 & 1.94 & 88.12 & 9.36 & 97.48 & 10.104 & 0.884 & 10.988 \\
\hline Beechcraft KingAir B-100 & 30.035 & 2.857 & 3.21 & 0.16 & 3.37 & 106.22 & 9.30 & 115.52 & 17.465 & 0.849 & 18.314 \\
\hline Bell Longranger IV & 31.334 & 2.980 & 0.78 & 0.16 & 0.94 & 183.61 & 8.92 & 192.53 & 15.921 & 3.184 & 19.105 \\
\hline
\end{tabular}




\section{Appendix 4}

See Tables 10 and 11.

Table 10 Energy consumption repartition for different kinds of vehicles

\begin{tabular}{|c|c|c|c|c|c|c|c|c|c|}
\hline $\begin{array}{l}\text { Vehicle characteristics } \\
\text { Vehicle type }\end{array}$ & & $\mathrm{MJ} / \mathrm{km}$ & $\begin{array}{l}\text { Engine } \\
\mathrm{MJ} / \mathrm{km}\end{array}$ & $\begin{array}{l}\text { Standby } \\
\mathrm{MJ} / \mathrm{km}\end{array}$ & $\begin{array}{l}\text { Powertrain } \\
\mathrm{MJ} / \mathrm{km}\end{array}$ & $\begin{array}{l}\text { Rolling } \\
\mathrm{MJ} / \mathrm{km}\end{array}$ & $\begin{array}{l}\text { Drag } \\
\mathrm{MJ} / \mathrm{km}\end{array}$ & $\begin{array}{l}\text { Kinetic } \\
\mathrm{MJ} / \mathrm{km}\end{array}$ & $\begin{array}{l}\mathrm{CO}_{2} \text { emitted } \\
\mathrm{g} \mathrm{CO}_{2} / \mathrm{km}\end{array}$ \\
\hline Light motorcycle & comb & 1.04 & 0.74 & 0.03 & 0.05 & 0.06 & 0.06 & 0.08 & 93.00 \\
\hline New small gas/electric hybrid & comb & 1.12 & 0.80 & 0.04 & 0.05 & 0.07 & 0.07 & 0.09 & 100.10 \\
\hline \multirow[t]{3}{*}{ Small gas auto } & hwy & 1.95 & 1.35 & 0.01 & 0.10 & 0.17 & 0.25 & 0.07 & 175.10 \\
\hline & city & 2.38 & 1.76 & 0.14 & 0.10 & 0.10 & 0.07 & 0.21 & 215.50 \\
\hline & comb & 2.17 & 1.56 & 0.08 & 0.10 & 0.14 & 0.16 & 0.14 & 195.30 \\
\hline \multirow[t]{3}{*}{ Medium gas auto } & hwy & 2.08 & 1.44 & 0.01 & 0.10 & 0.19 & 0.27 & 0.08 & 186.80 \\
\hline & city & 2.82 & 2.09 & 0.17 & 0.11 & 0.12 & 0.08 & 0.25 & 254.70 \\
\hline & comb & 2.45 & 1.76 & 0.09 & 0.11 & 0.15 & 0.17 & 0.16 & 220.75 \\
\hline \multirow[t]{3}{*}{ Medium station wagon } & hwy & 2.30 & 1.70 & 0.14 & 0.09 & 0.10 & 0.07 & 0.20 & 207.50 \\
\hline & city & 3.15 & 2.18 & 0.02 & 0.16 & 0.28 & 0.40 & 0.12 & 280.10 \\
\hline & comb & 2.73 & 1.94 & 0.08 & 0.12 & 0.19 & 0.23 & 0.16 & 243.80 \\
\hline \multirow[t]{3}{*}{ Large gas automobile } & hwy & 2.41 & 1.61 & 0.09 & 0.11 & 0.19 & 0.27 & 0.14 & 224.10 \\
\hline & city & 3.42 & 2.40 & 0.19 & 0.21 & 0.15 & 0.13 & 0.34 & 311.30 \\
\hline & comb & 2.92 & 2.01 & 0.14 & 0.16 & 0.17 & 0.20 & 0.24 & 267.70 \\
\hline \multirow[t]{3}{*}{ Diesel automobile } & hwy & 2.21 & 1.53 & 0.01 & 0.11 & 0.20 & 0.28 & 0.08 & 197.17 \\
\hline & city & 2.99 & 2.22 & 0.18 & 0.12 & 0.13 & 0.09 & 0.26 & 268.83 \\
\hline & comb & 2.71 & 1.92 & 0.11 & 0.13 & 0.17 & 0.19 & 0.19 & 233.00 \\
\hline \multirow[t]{3}{*}{ Mini van } & hwy & 12.52 & 2.07 & 0.26 & 2.19 & 3.05 & 3.87 & 1.08 & 233.50 \\
\hline & city & 3.46 & 2.56 & 0.21 & 0.14 & 0.15 & 0.10 & 0.30 & 318.38 \\
\hline & comb & 7.99 & 2.31 & 0.23 & 1.16 & 1.60 & 1.99 & 0.69 & 275.94 \\
\hline \multirow[t]{3}{*}{ Mid size. pick-up trucks } & hwy & 2.85 & 1.97 & 0.01 & 0.14 & 0.25 & 0.36 & 0.10 & 254.70 \\
\hline & city & 3.77 & 2.79 & 0.23 & 0.15 & 0.17 & 0.11 & 0.33 & 346.65 \\
\hline & comb & 3.31 & 2.38 & 0.12 & 0.15 & 0.21 & 0.24 & 0.22 & 300.67 \\
\hline \multirow[t]{3}{*}{ Large LPG automobile } & hwy & 2.40 & 1.61 & 0.09 & 0.11 & 0.19 & 0.27 & 0.14 & 222.68 \\
\hline & city & 3.45 & 2.55 & 0.21 & 0.14 & 0.15 & 0.10 & 0.30 & 309.32 \\
\hline & comb & 2.91 & 2.00 & 0.14 & 0.16 & 0.17 & 0.20 & 0.24 & 266.00 \\
\hline \multirow[t]{3}{*}{ Large van } & hwy & 3.50 & 2.42 & 0.02 & 0.17 & 0.31 & 0.45 & 0.13 & 311.30 \\
\hline & city & 4.62 & 3.42 & 0.28 & 0.18 & 0.20 & 0.13 & 0.40 & 425.32 \\
\hline & comb & 4.06 & 2.92 & 0.15 & 0.18 & 0.26 & 0.29 & 0.27 & 368.31 \\
\hline \multirow[t]{3}{*}{ Large pick-up truck } & hwy & 3.68 & 2.55 & 0.02 & 0.18 & 0.33 & 0.47 & 0.13 & 329.00 \\
\hline & city & 4.14 & 3.06 & 0.25 & 0.17 & 0.18 & 0.12 & 0.36 & 329.60 \\
\hline & comb & 3.91 & 2.81 & 0.13 & 0.17 & 0.25 & 0.29 & 0.25 & 329.30 \\
\hline \multirow[t]{3}{*}{ Diesel light truck } & hwy & 3.27 & 2.27 & 0.02 & 0.16 & 0.29 & 0.42 & 0.12 & 291.29 \\
\hline & city & 4.41 & 3.26 & 0.26 & 0.18 & 0.19 & 0.13 & 0.38 & 405.43 \\
\hline & comb & 4.16 & 2.99 & 0.15 & 0.18 & 0.26 & 0.30 & 0.27 & 377.32 \\
\hline \multirow[t]{3}{*}{ Gasoline light truck } & hwy & 3.51 & 2.43 & 0.02 & 0.17 & 0.31 & 0.45 & 0.13 & 313.84 \\
\hline & city & 4.73 & 3.50 & 0.28 & 0.19 & 0.21 & 0.14 & 0.41 & 376.20 \\
\hline & comb & 4.46 & 3.20 & 0.15 & 0.20 & 0.29 & 0.34 & 0.28 & 375.86 \\
\hline \multirow[t]{3}{*}{ Diesel heavy truck } & hwy & 6.82 & 4.16 & 0.07 & 0.35 & 0.77 & 1.30 & 0.18 & 680.37 \\
\hline & city & 9.22 & 6.13 & 0.47 & 0.75 & 0.41 & 0.41 & 1.04 & 925.91 \\
\hline & comb & 8.02 & 5.14 & 0.27 & 0.55 & 0.59 & 0.86 & 0.61 & 870.00 \\
\hline \multirow[t]{3}{*}{ Diesel bus } & hwy & 6.68 & 4.01 & 0.10 & 0.33 & 0.81 & 1.24 & 0.19 & 706.91 \\
\hline & city & 9.10 & 5.64 & 0.73 & 0.73 & 0.40 & 0.33 & 1.27 & 1034.60 \\
\hline & comb & 7.89 & 4.83 & 0.41 & 0.53 & 0.60 & 0.79 & 0.73 & 870.75 \\
\hline \multirow[t]{3}{*}{ Gasoline heavy truck } & hwy & 7.96 & 4.86 & 0.08 & 0.40 & 0.90 & 1.51 & 0.21 & 722.60 \\
\hline & city & 10.77 & 7.16 & 0.55 & 0.88 & 0.48 & 0.48 & 1.21 & 983.38 \\
\hline & comb & 10.12 & 6.73 & 0.52 & 0.83 & 0.46 & 0.46 & 1.14 & 924.00 \\
\hline
\end{tabular}




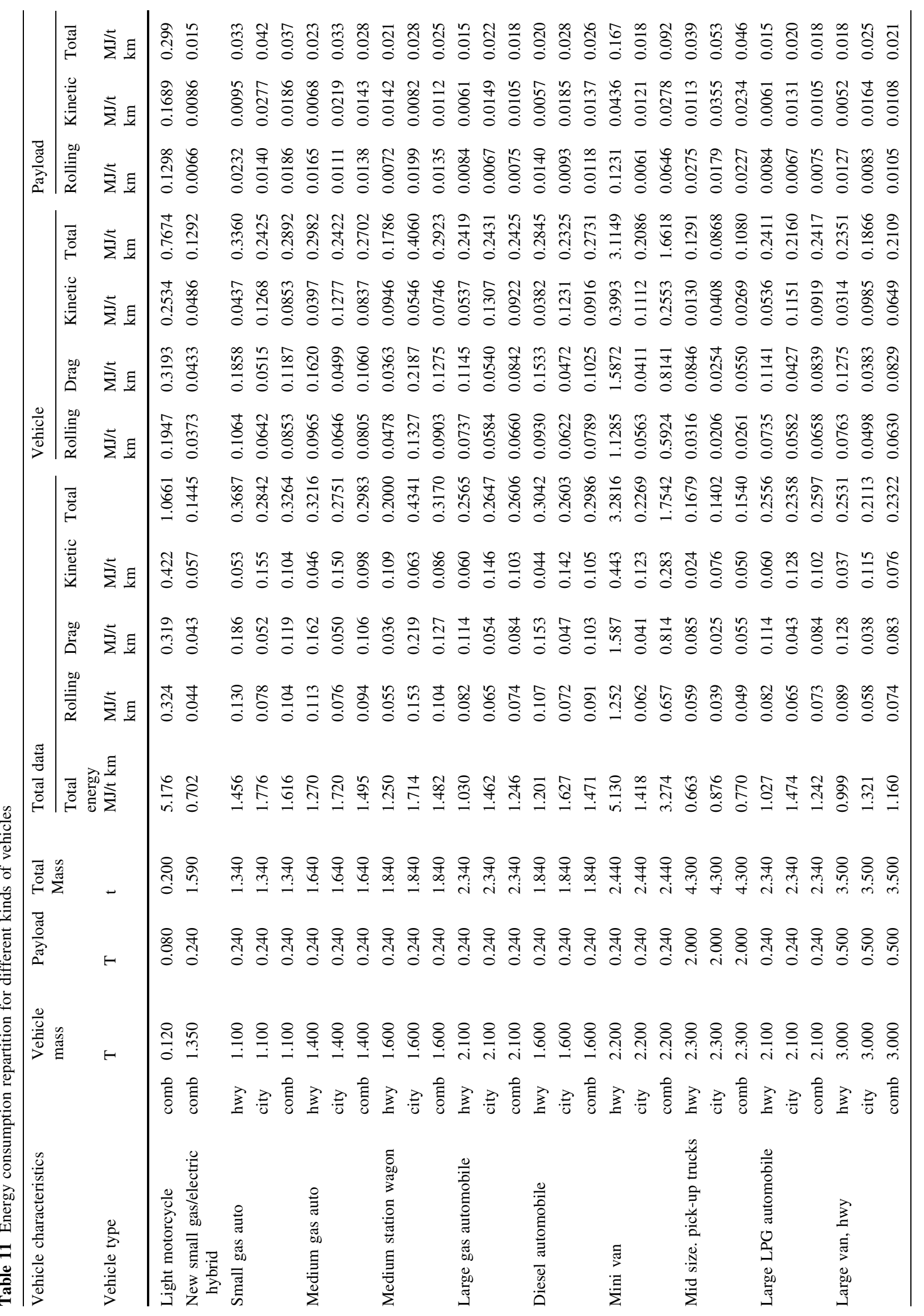




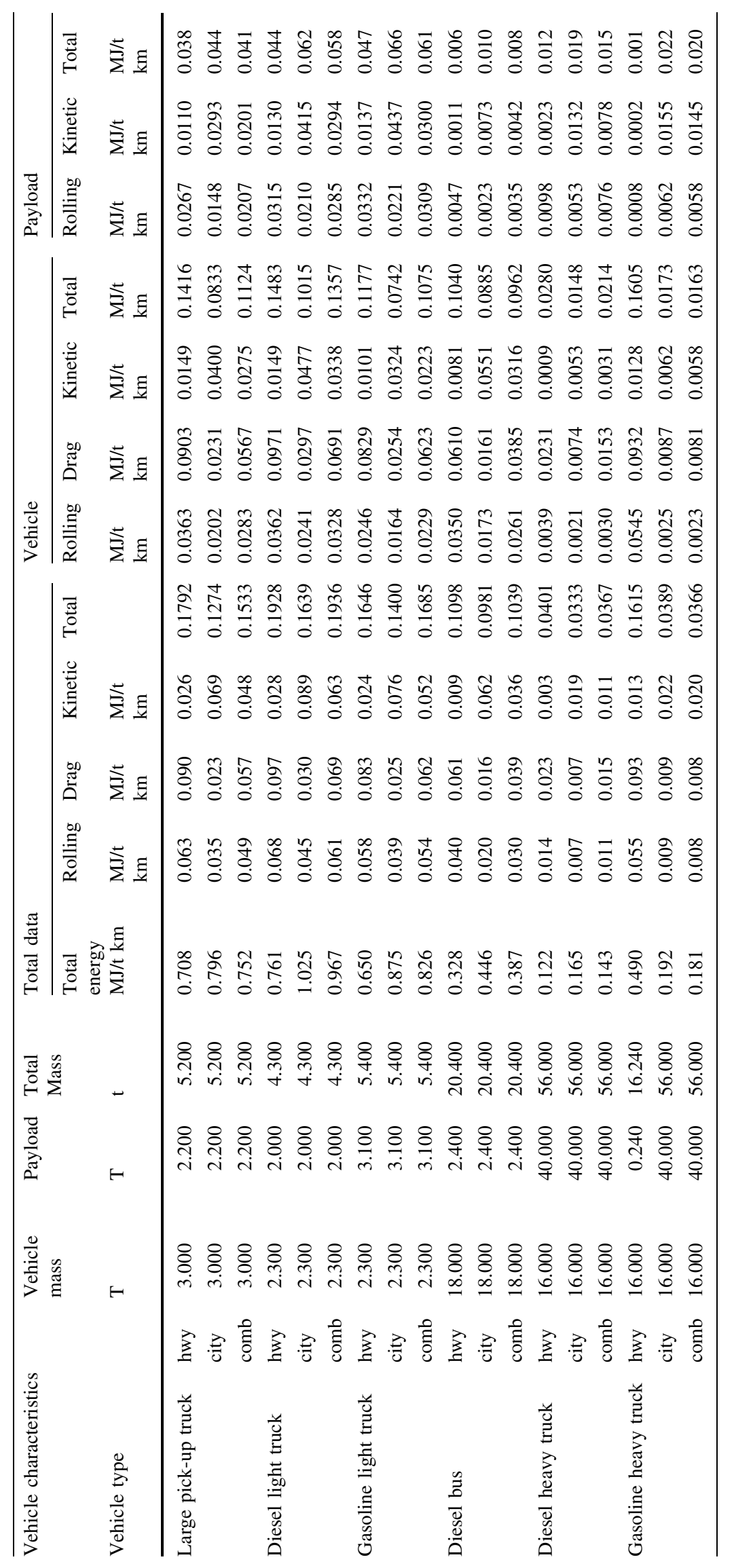




\section{References}

1. VV.AA. World Energy Outlook 2013, International Energy Agency (2013)

2. VV.AA. "2014 World Energy Issues Monitor", World Energy Council, London (2014)

3. Gabrielli, G., von Karman, Th: What price speed? Mech. Eng. 72, 775-781 (1950)

4. Stamper, J.:"Time is Energy," Aeronaut. J. 169-178 (1975)

5. Teitler, S., Proodian, R.E.: "What price speed, revisted," J. Energy., 4(1),46-48 (1980). http://www.neodymics.com/Images/ EPPaper050323I.pdf via the Internet

6. Minetti, A., Pinkerton, J., Zamparo, P.: From bipedalism to bicyclism, evolution in energetics and biomechanics of historic bicycles. Proc. R. Soc. Lond. B 268, 1351-1360 (2001)

7. Young, J., Smith, R., Hillmansen, S.: What price speed-revisited. Ingenia 22, 46-51 (2005)

8. Hobson, A.: Physics literacy, energy and the environment. Phys. Educ. 38, 109-114 (2003)

9. Radtke, J.: The energetic performance of vehicles. Open. Fuel. Energy. Sci. J 1, 11-18 (2008)

10. VV. AA., "MPG Ratings, 2007 Model Year", US Department of Energy (2007). Available: http://www.fueleconomy.gov/

11. Dewulf, J., Van Langenhove, H.: Exergetic material input per unit of service (EMIPS) for the assessment of resource productivity of transport commodities. Resour. Conserv. Recycl. 38(2), 161-174 (2003)

12. Chester, M., Horvath, A. Environmental assessment of passenger transportation should include infrastructure and supply chains. Environ. Res. Lett. 4(2) (2009)

13. Chester, M., Horvath, A. High-speed rail with emerging automobiles and aircraft can reduce environmental impacts in california's future. Environ. Res. Lett. 7(3) (2012)

14. Chester et al. "Infrastructure and automobile shifts: positioning transit to reduce life-cycle environmental impacts for urban sustainability goals", Environ. Res. Lett. 8(1) (2012)

15. VV.AA. "IPCC Fourth Assessment Report: Climate Change 2007", Intergovernmental Panel on Climate Change (2007)

16. VV.AA. International Energy Outlook 2013, (IEO2013) U.S. Energy Information Administration, Washington DC (2013)

17. VV.AA. Recycling - Cost analysis and energy balance Australian Environmental Protection Authority, Bulletin 409, (1990)

18. VV.AA. "Nissan Motor Company Sustainability Report 2013", Nissan Motor Company (2013)

19. Choate, A., Pederson, L., Scharfenberg, J., Ferland, H.: Waste management and energy savings: benefits by the numbers. Environmental Protection Agency, Washington DC (2005)

20. Das, S.: and Randall Curlee T. Recycling of new generation vehicles. Oak Ridge National Laboratory, USA (1999)

21. Osiński, J. Vehicles recycling system problems. Recykling. 36 (3) 2009

22. Tavoularis, G., et al.: Management of the end-of-life vehicles stream in Romania. In: Cossu, R., Diaz, L.F., Stegmann, R. (eds.) The 12th International Waste Management and Landfill Symposium. Sardinia, Italy (2009)
23. Elghali, L., McColl-Grubb, V., Schiavi, I., Griffiths, P.: Sustainable resource use in the motor industry: a mass balance approach. VIRIDIS Report, UK (2004)

24. VV.AA., Product Specification. TUPRAS, Izmit, Turkey (1996)

25. VV.AA. "Mobility 2030 Report: Meeting the Challenges to Sustainability", World Business Council for Sustainable Development (WBCSD) (2004)

26. Hargroves, K., von Weizsacke, E.: Technology and policy options for making transport systems more sustainable. United Nations Dept. of Economic and Social Affairs, Commission on Sustainable Development, Nineteenth Session, New York (2011)

27. VV.AA., "GREET 1 Model 2012"Argonne. National Laboratory, USA (2012)

28. VV.AA., "Calculating CO2 Emissions from Mobile Sources", GHG Protocol - Mobile Guide, The Greenhouse Gas Protocol (2012)

29. VV.AA., "Compendium of Greenhouse Gas, Emissions Estimation Methodologies for the Oil and Gas Industry", American Petroleum Institute (2001)

30. Strickland, J. Energy Efficiency of different modes of transportation. (2009)

31. http://www.builditsolar.com/References/EfficiencyTransport/ strickland.htm

32. Brannigan, C., Gibson, G., Hill N., Dittrich, M., Schroten, A., van Essen, H., van Grinsven, A.: Development of a better understanding of the scale of co-benefits associated with transport sector GHG reduction policies, EU Transport GHG: Routes to 2050 II project, Founded by EU, Updated 12 July 2012

33. Sovran, G., Bohn, M. "Formulae for the tractive energy requirements of vehicles driving the epa schedules." SAE paper 810184, (1981)

34. Bejan, A.: Advanced Engineering Thermodynamics, 2nd edn. Wiley, New York (1997)

35. Bejan, A.: Shape and structure, from engineering to nature. Cambridge University Press, Cambridge (2000)

36. Bejan, A., Lorente, S.: The constructal law and the evolution of design in nature. Phys. Life. Rev. 8(3), 209-240 (2011)

37. Bejan, A., Marden, J. "Constructing animal locomotion from new thermodynamics theory". Am. Sci. 94(4) (2006)

38. Bejan, A., Lorente, S.: Constructal law of design and evolution: physics, biology, technology, and society. J. Appl. Phys. 113, 151301 (2013)

39. Dumas, A., Madonia, M., Trancossi, M., Vucinic, D.: Propulsion of photovoltaic cruiser-feeder airships dimensioning by constructal design for efficiency method. SAE. Int. J. Aerosp. 6(1), 273-285 (2013). doi:10.4271/2013-01-2303

40. Dumas, A., Trancossi, M., Madonia, M.: Energetic design and optimization of a large photovoltaic stratospheric unconventional feeder Airship. SAE. Int. J. Aerosp. 5(2), 354-370 (2012). doi:10. 4271/2012-01-2166

41. Trancossi, M., Dumas, A., Madonia, M., "Optimization of airships with constructal design for efficiency method", SAE Technical Paper 2013-01-2168, (2013). doi:10.4271/2013-01-2168

42. Trancossi, M., Dumas, A., Madonia, M., "Energy and mission optimization of an airship by constructal design for efficiency method”, ASME IMECE 2013. San Diego, California (2013) 